\title{
NANO TREATMENT OF DECAYED CEMENT-LIME MORTARS FROM THE EDFENA ROYAL PALACE (ROSETTA, EGYPT)
}

\author{
Abubakr MOUSSA \\ Department of Conservation, Faculty of Archaeology, Cairo University, Egypt
}

E.mail: dr_abubakr@msn.com

\begin{abstract}
This article focuses on the identification of the used building materials and their most common degradation factors at the royal palace of king Farouk at Edfena, Rosetta, Egypt; and then assessing the most appropriate nano-consolidants for the decayed lime-based mortars at the palace, to achieve the target of this study; building materials were studied by means of XRD, FTIR spectroscopy and light optical microscope; in order to find out if there are any chemical decomposition or any physical failure. Halite salt was detected in the building limestone; mortars' composition varies between lime and white Portland cement, while the plaster in the palace walls is a mixture of white Portland cement and lime. Plaster in the marina is a mixture of lime, white Portland cement and anhydrite. Pigment material in the green terrazzo is a mix of malachite and greenalite; portlandite abreast with brucite were found in the plaster and mortar mixtures in addition to clay minerals. Nanolime, nanotitanium, nanokaolin, nanosilica and multiwalled carbon nanotubes were used as consolidants, experimental study made it clear that nanotitanium and MWCNTs are the most appropriate consolidants in the current case study.
\end{abstract}

\section{KEYWORDS}

Royal Palace; XRD analysis; IR spectroscopy; Building materials; Deterioration factors; nanolime; nanotitanium; nanokaolin; nanosilica; MWCNTs
تسلط هذه الدراسة الضوء على التعرف على مواد البناء

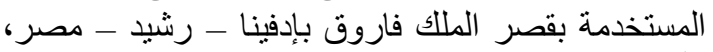
وأهم عوامل التلف المؤثرة عليها، مستتبعة ذلك بتحديد أنسب المواد النانوية التي يمكن استخدامها في عمليات تقوية المونات بالقصر وخصوصاً تللك المعتمدة على الجيل الجير

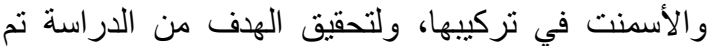
تحليل مواد البناء بواسطة حيود الأشعة السينية وطيف

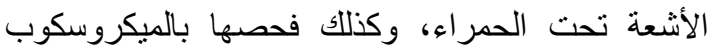

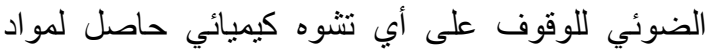
البناء علاوة على الأضرار الفيزيائية، وقد تبين ولئين وجود ملح

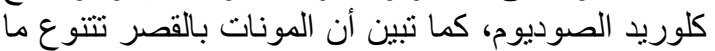

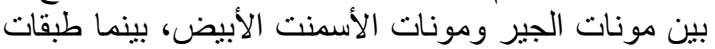
الثيد على حوائط القصر عبارة عن الجير التير المخلوط بالأسمنت الأبيض، أما طبقات التحضير بمرسى القهى القصر

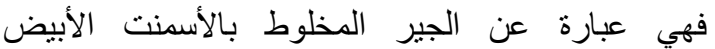
و الجبس، كما تبين أن المادة الملونة للطيرازو الأخضر الأخر

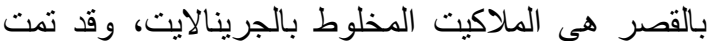

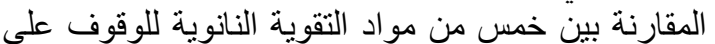
أنسبها للإستخدام وهي نانو الجير، نانئ نانو السيليكا، نانو

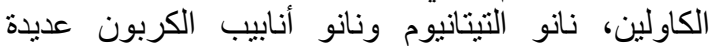

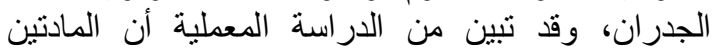
الأخيرتين هما الأنسب للإستخدام والأكثر فاعلية.

الكلمات الدالة

قصر الملك فاروق، إدفينا، رشيد، عوامل التلف، تقوية المونات، نانو الجير، نانو السيليكا، نانو، الكاولين، نانو، التيتانيوم 


\section{INTRODUCTION}

Rosetta is a port city of the Nile delta, located about $65 \mathrm{~km}$ east of Alexandria. Historically; Rosetta is famous for the much known monument "Rosetta stone", the city has boomed since 969 A.D parallel to the establishment of the Fatimid state in Egypt. ${ }^{1}$ Edfena is about $10 \mathrm{~km}$ to the south of Rosetta; this village is widely known by its famous archeries which were built by King Farouk in 1949. King Farouk royal palace in Edfena (figure 1); is situated at the southern bank of the river Nile; about one kilometer to the north of the Edfena archeries. This palace was constructed in three stages: the first was in the era of Khedive Abbas Helmi II (1892-1914), the second was in the era of King Ahmed Fouad I (1917-1936), and the third was in the era of King Farouk (1937-1952). ${ }^{2}$
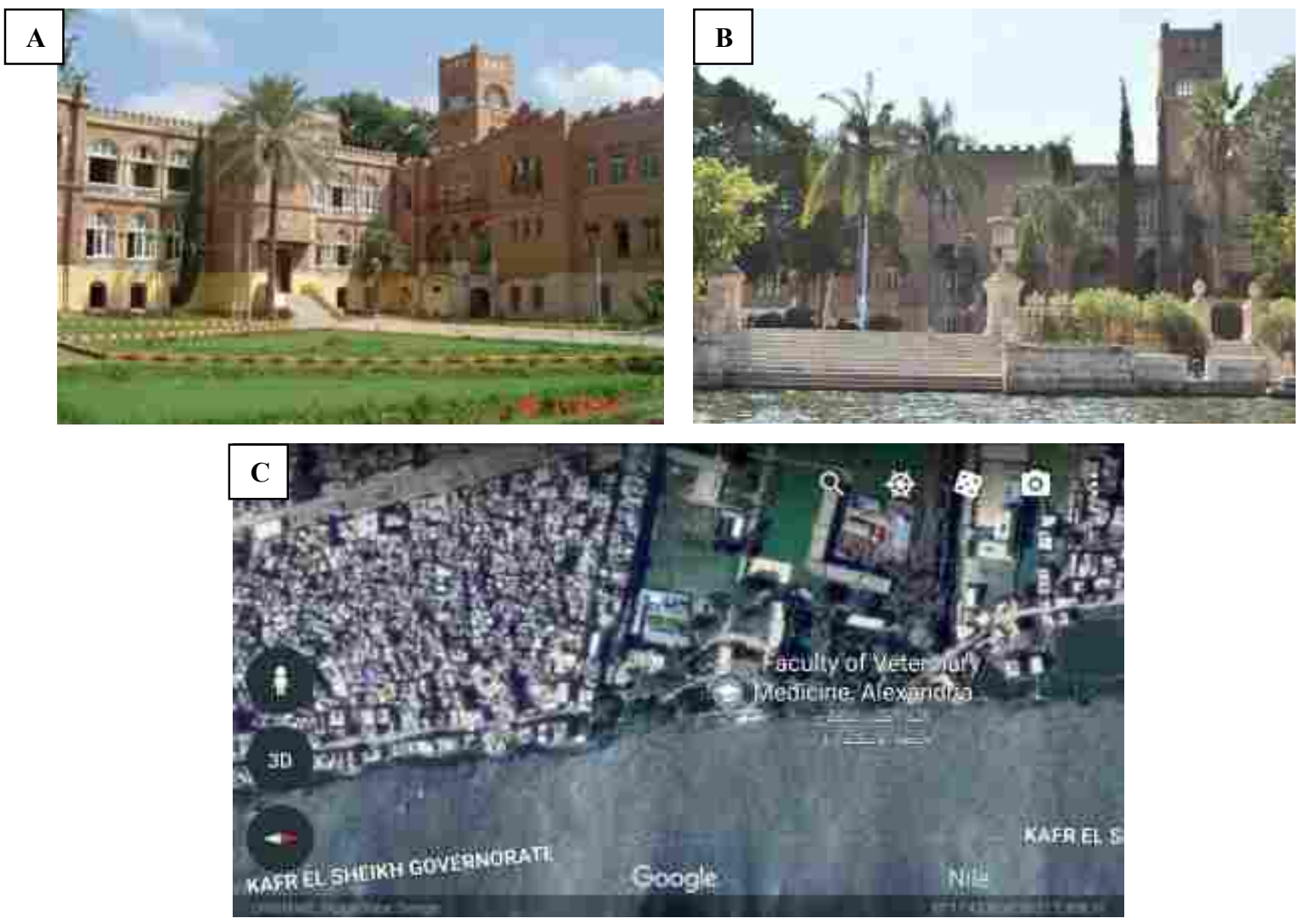

Figure 1: A: Façade. B: back view. C: Google earth location of the royal palace at Edfena and its Nile river marina

Design principles for residential buildings, whether they are large buildings or small houses, are almost the same and based on the idea of the inward design pattern and separation between men and women. ${ }^{3}$ The Edfena palace is composed of three pavilions "suites" completing the shape of the Latin letter "L"; every pavilion is three floors. The palace elements are gathered around a square or rectangular internal courtyard from which vertical and horizontal movement is distributed around the different elements and activities. Ground floor contains, in addition to the ground $q a^{\prime} a$, the takhtabaush, the bent entrance and the

\footnotetext{
${ }^{1}$ Cortese, "The Nile", pp. 20-29.

${ }^{2}$ Overton, Some Aspects, p. 35.

${ }^{3}$ Burgoyne, Mamluk Jerusalem, p. 53.
}

- 231 - Nano Treatment of Decayed Cement-Lime Mortars from the Edfena Royal Palace 
stair cases to the upper floors, rooms for servants, utilities, depots and a mill and water wheel. While the upper floors contain qa'as, sleeping closets, living rooms and services. The design has taken into account the vertical separation between the services in the ground floor and the living and sleeping quarters in the upper floors, as well as separating, vertically and horizontally, between the wing of the household 'Haramlik' and living quarters for guests and men 'Salamlik'. This palace has been used as a campus for the faculty of Veterinary, Alexandria University, since $1974 .^{4}$

The present study aims basically to assess the chemical composition of building materials at the Edfena royal palace, and then assessing their decay agents, the study also makes it possible to know the most suitable Nano material for cement-lime mortars consolidation.

\section{MATERIALS AND METHODS}

Limestone, mortars, plasters, historic terrazzo, redbrick and ornaments from the King Farouk royal palace at Edfena were sampled and prepared for laboratory analyses to determine their chemical composition. Samples were grinded and pulverized; X-ray diffraction (XRD) analysis was performed using these powdered samples of the above mentioned building materials using a Philips (PW1840) diffractometer with Ni-filtered $\mathrm{Cu}$ $\mathrm{K} \alpha$ radiation. The samples were scanned over the $5-60^{\circ} 2 \theta$ intervals at a scanning speed of $1.2^{\circ} \mathrm{min}^{-1}$. A quantitative estimate of the abundance of the mineral phases was derived from the XRD data using the intensity of certain reflections and external standard mixtures of minerals compared to the JCPDS standards of $1967 . .^{5}$ On the other hand; due to the sensitivity of the FTIR instrument, the most convenient and satisfactory method involves simple evaporation of the sample solution (using a solvent such as: chloroform, ether, dichloromethane) onto a $\mathrm{KBr}$ salt plate and acquisition of the spectrum from the thin film remaining. The estimated time to obtain FTIR spectrum from a routine sample varies from 1 to 10 minutes. $^{6}$ Additionally; liquids, dried residues, viscous materials, films, and other sample matrices can be accommodated. The testing is generally performed in accordance with ASTM E334. The FTIR aids in identifying chemical bonds, and thus chemical composition of materials. FTIR works best when the sample matrix is either homogeneous; or composed of only a few materials. Mixtures of multiple materials tend to "confuse" the library search function due to complexity of overlapping spectral fingerprints. The samples of Edfena royal palace were analyzed as $\mathrm{KBr}$ pellet by a JASCO FTIR spectrometer (model $460,400-4000 \mathrm{~cm}^{-1}, 4 \mathrm{~cm}^{-1}$ resolution), in the transmission mode. Some samples were investigated using digital USB light optical microscope with magnification power (500x). Concerning Nano treatment; cement-lime mortar was sampled for consolidation process. Five different Nano-consolidants were used in comparison; nanolime (NL) 5\%, nanotitanium (NT) 5\%, nanokaolin (NK) 5\%, nanosilica (NS) 5\% and multi-walled carbon nanotubes (MWCNTs) 5\%, all the consolidants were dispersed in water and alcohol (5050); except of nanosilica which was dispersed in Paraloid B72 3\% in acetone, and MWCNTs which was dispersed in polycarboxylate and alcohol (table 1). Mortar samples were submerged in nanosolutions for 24 hours in the room temperature, specimens were then left to dry in the same ambient environment for one week, the treated samples were then investigated by mean of scanning electron microscope (SEM), the study was performed using a Fei company device (version quanta 200), with specifications of: Kv:

\footnotetext{
${ }^{4}$ Creswell, The Muslim Architecture, p. 135; Burgoyne, Mamluk Jerusalem, p. 54; Abouseif, Islamic Architecture, p.89.

${ }^{5}$ JCPDS standards.

${ }^{6} \mathrm{Hsu}$, Infrared Spectroscopy, p. 115.
} 
24.98; tilt (0.00); take-off: (36.47); ampt (35.0); detector type (SUTW-sapphire); resolution (129.87).

Table 1: The nano-materials used in consolidation treatment of cement-lime mortars

\begin{tabular}{|c|c|c|c|c|c|}
\hline & Supplier & Chemical formula & Dilution & Disperser & Application \\
\hline NL & IBZ-SALZCHEMIE & $\mathrm{Ca}(\mathrm{OH})_{2}$ & $5 \%$ & Water, alcohol (50-50) & immersion \\
\hline $\mathbf{N T}$ & NANOSHEL & $\mathrm{TiO}_{2}$ & $5 \%$ & Water, alcohol (50-50) & immersion \\
\hline $\mathbf{N K}$ & NANOSHEL & $\mathrm{Al}_{2} \mathrm{Si}_{2} \mathrm{O}_{5}(\mathrm{OH})_{4}$ & $5 \%$ & Water, alcohol (50-50) & immersion \\
\hline NS & NANOSHEL & $\mathrm{SiO}_{2}$ & $5 \%$ & Paraloid 3\% in acetone & immersion \\
\hline MWCNTs & TUBALL & $\mathrm{C}$ & $5 \%$ & $\begin{array}{r}\text { polycarboxylate and } \\
\text { alcohol }\end{array}$ & immersion \\
\hline
\end{tabular}

\section{RESULTS}

XRD Results: Two limestone samples were analyzed from the palace; the first was derived from the marina of the palace and consists of $85 \%$ calcite $\left(\mathrm{CaCO}_{3}\right), 9 \%$ dolomite $\left[\mathrm{CaMg}\left(\mathrm{CO}_{3}\right)_{2}\right]$ and $6 \%$ halite $(\mathrm{NaCl})$; (figure 2).The second limestone sample was taken from the northern wall of the palace and consists of $86 \%$ dolomite $\left[\mathrm{CaMg}\left(\mathrm{CO}_{3}\right)_{2}\right]$; and $14 \%$ calcite $\left(\mathrm{CaCO}_{3}\right)$; (figure 3). Two redbrick samples were also examined by mean of XRD; the first is a marina sample and consists of $44 \%$ quartz $\left(\mathrm{SiO}_{2}\right) ; 28 \%$ illite $\left[\mathrm{KMgTiAl}_{2} \mathrm{Si}_{3} 10(\mathrm{OH})_{2}\right] ; \quad 22 \%$ hematite $\left(\mathrm{Fe}_{2} \mathrm{O}_{3}\right)$ and $6 \%$ muscovite $\left[\mathrm{KAl}_{2}\left(\mathrm{AlSi}_{3} \mathrm{O}_{10}\right) \mathrm{F}(\mathrm{OH})_{2}\right]$; (figure 4). The second redbrick sample was taken from the palace northern wall and composes of $47 \%$ quartz $\left(\mathrm{SiO}_{2}\right) ; 26 \%$ diopside $\left(\mathrm{CaMgSi}_{2} \mathrm{O}_{6}\right) ; 17 \%$ calcite $\left(\mathrm{CaCO}_{3}\right)$ and $10 \%$ hematite $\left(\mathrm{Fe}_{2} \mathrm{O}_{3}\right)$; (figure 5). Concerning mortars; three mortar samples were analyzed; the first one represents the joints between limestone blocks; the sample contains; $71 \%$ calcite $\left(\mathrm{CaCO}_{3}\right)$; and $29 \%$ quartz $\left(\mathrm{SiO}_{2}\right)$; (figure 6). The second mortar sample represents the joints between the redbrick units and contains; $56 \%$ calcite $\left(\mathrm{CaCO}_{3}\right)$; $34 \%$ quartz $\left(\mathrm{SiO}_{2}\right)$ and $10 \%$ albite $\left(\mathrm{NaAlSi}_{3} \mathrm{O}_{8}\right)$; (figure 7). The third mortar sample represents the bedding layer of the mosaics and the terrazzo inside the palace; the sample contains; $71 \%$ calcite $\left(\mathrm{CaCO}_{3}\right) ; 17 \%$ albite $\left(\mathrm{NaAlSi}_{3} \mathrm{O}_{8}\right) ; 6 \%$ quartz $\left(\mathrm{SiO}_{2}\right)$ and $6 \%$ hematite $\left(\mathrm{SiO}_{2}\right)$; (figure 8). The plaster was also analyzed to find out if it has the same chemical composition of the mortars or it is different. Two samples were examined; the first was

\footnotetext{
- 233 - Nano Treatment of Decayed Cement-Lime Mortars from the Edfena Royal Palace
} 
taken from the palace walls and contains; $44 \%$ albite $\left(\mathrm{NaAlSi}_{3} \mathrm{O}_{8}\right) ; 33 \%$ calcite $\left(\mathrm{CaCO}_{3}\right)$; $12 \%$ quartz $\left(\mathrm{SiO}_{2}\right)$; and $11 \%$ brucite $\left[\mathrm{Mg}(\mathrm{OH})_{2}\right]$; (figure 9). The second plaster sample is from the marina ornamentations; the sample contains $38 \%$ calcite $\left(\mathrm{CaCO}_{3}\right) ; 23 \%$ quartz $\left(\mathrm{SiO}_{2}\right) ; 21 \%$ albite $\left(\mathrm{NaAlSi}_{3} \mathrm{O}_{8}\right)$ and $18 \%$ anhydrite $\left(\mathrm{CaSO}_{4}\right)$; (figure 10). The last XRD sample was a green terrazzo sample derived from the front eastern balcony of the palace; due to XRD analysis; the sample composes of $62 \%$ calcite $\left(\mathrm{CaCO}_{3}\right) ; 16 \%$ albite $\left(\mathrm{NaAlSi}_{3} \mathrm{O}_{8}\right) ; 9 \%$ malachite $\left[\mathrm{Cu} 2 \mathrm{CO} 3(\mathrm{OH})_{2}\right] ; 5 \%$ portlandite $\left[\mathrm{Ca}(\mathrm{OH})_{2}\right] ; 4 \%$ greenalite $\left[\mathrm{Fe}_{6} \mathrm{Si}_{4} \mathrm{O}_{10}(\mathrm{OH})_{2}\right]$ in addition to $4 \%$ brucite $\left[\mathrm{Mg}(\mathrm{OH})_{2}\right]$; (figure 11). XRD results are represented in table (2).

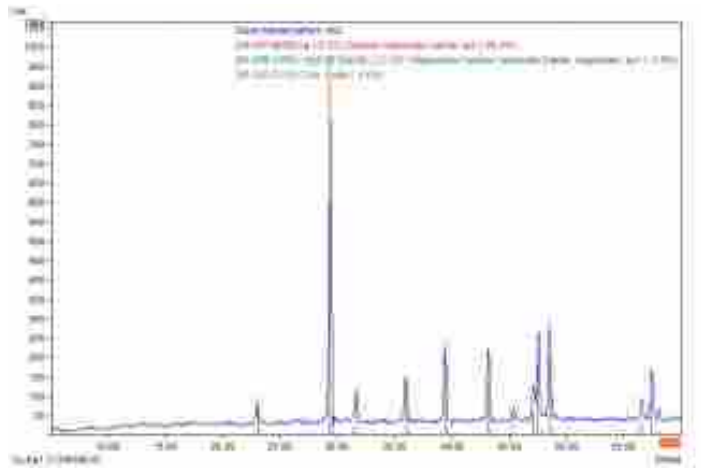

Figure 2: XRD pattern of the marina limestone sample reveals calcite as dominant component

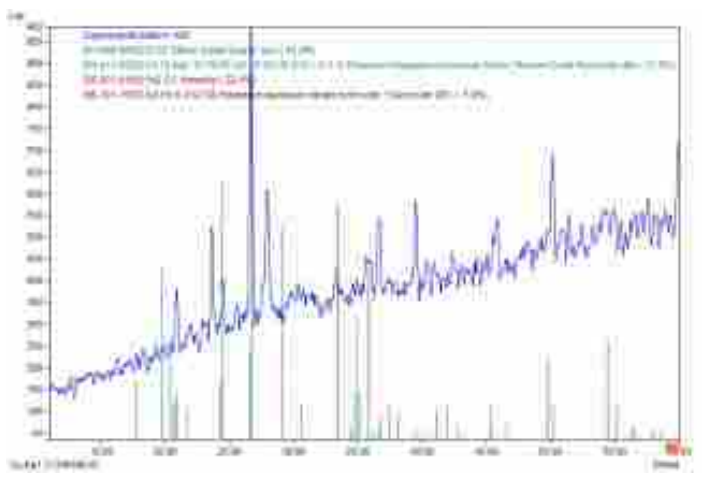

Figure 4: XRD pattern of the marina redbrick sample reveals quartz as main component abreast with illite

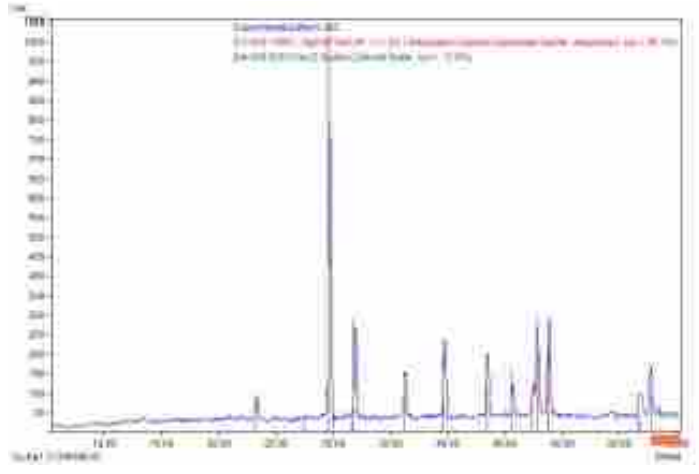

Figure 3: XRD pattern of the palace limestone sample reveals dolomite as dominant component

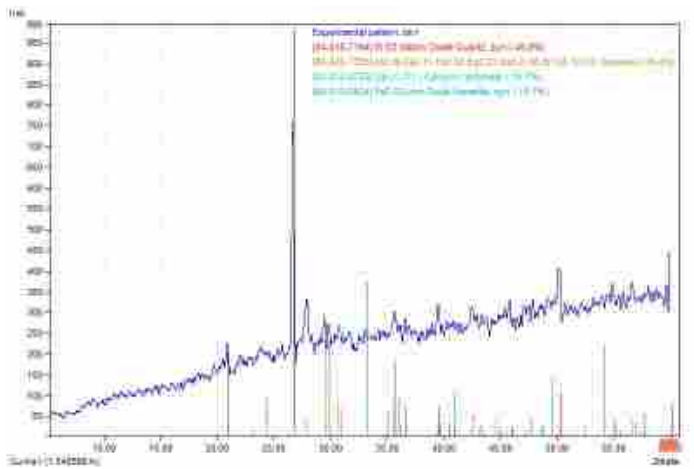

Figure 5: XRD pattern of the palace redbrick sample reveals quartz as main component abreast with diopside 


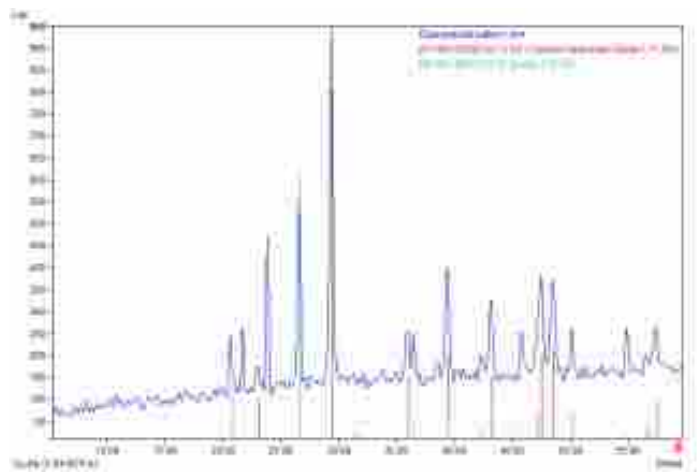

Figure 6: XRD pattern of the limestone mortar sample which is a pure lime mortar composes of calcite and quartz

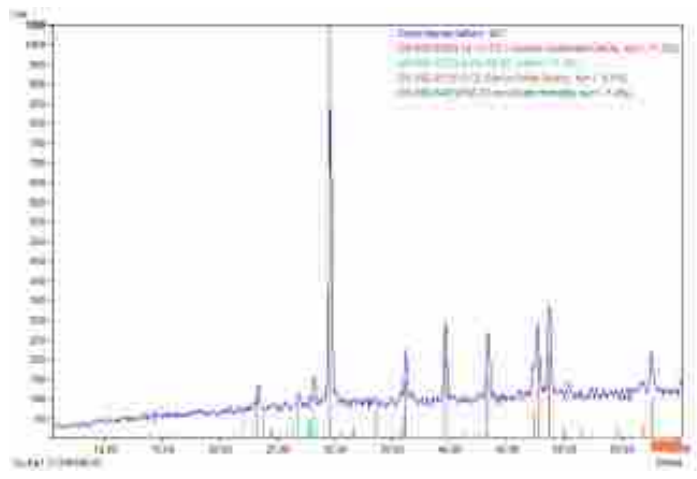

Figure 8: XRD pattern of the terrazzo mortar sample which is a cement-lime mortar

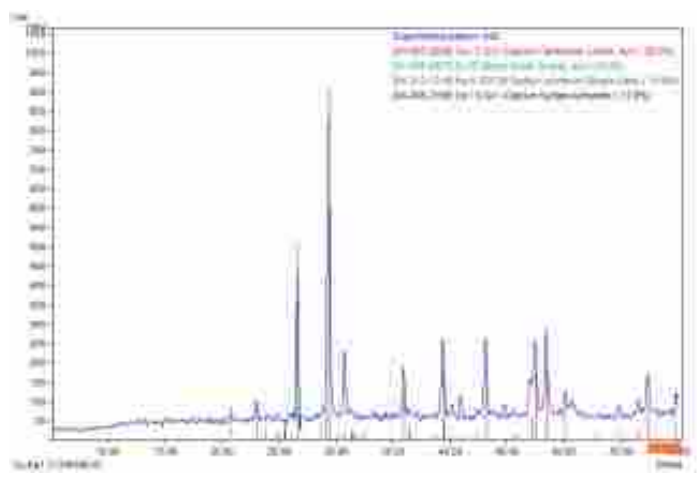

Figure 10: XRD pattern of a plaster sample from the marina which is a cement-lime plaster

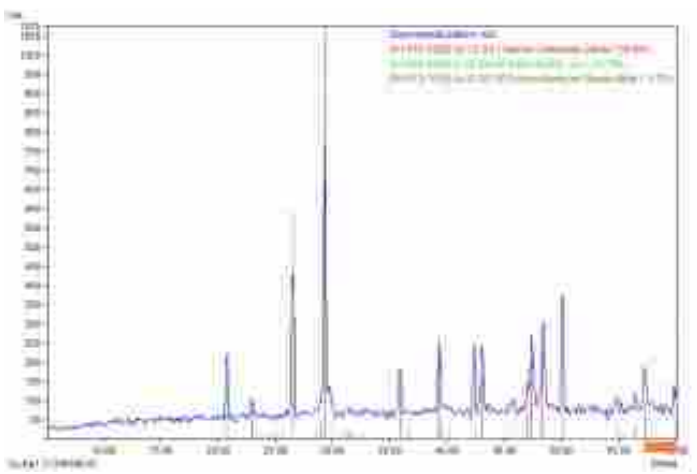

Figure 7: XRD pattern of the redbrick mortar sample which is a cement-lime mortar

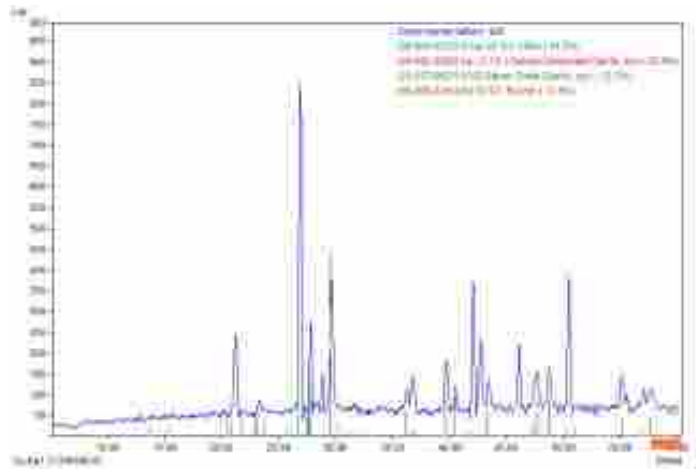

Figure 9: XRD pattern of a plaster sample from the palace which is a cement-lime plaster

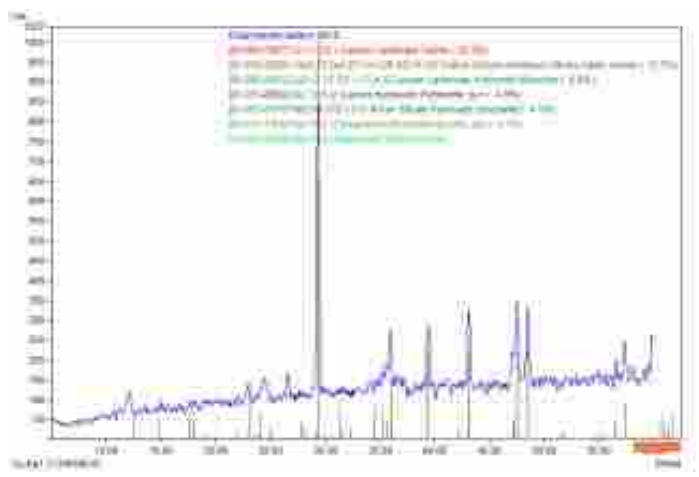

Figure 11: XRD pattern of a terrazzo sample from the palace reveals lime and cement as dominant components 
Table 2: Mineralogical composition (w/w \%) of Edfena royal palace archaeological samples

\begin{tabular}{|c|c|c|c|c|c|c|c|c|c|c|c|c|c|c|c|}
\hline Sample & Location & $\mathrm{Ca}$ & Do & Al & $\mathbf{Q u}$ & He & An & Ha & Di & $\mathrm{Br}$ & Ma & $\mathbf{G r}$ & Po & Mu & Il \\
\hline Limestone & Marina & 85 & 9 & -- & -- & -- & -- & 6 & -- & -- & -- & -- & -- & -- & -- \\
\hline Limestone & Palace & 14 & 86 & -- & -- & -- & -- & -- & -- & -- & -- & -- & -- & -- & -- \\
\hline Redbrick & Marina & -- & -- & -- & 44 & 22 & -- & -- & -- & -- & -- & -- & -- & 6 & 28 \\
\hline Redbrick & Palace & 17 & -- & -- & 47 & 10 & -- & -- & 26 & -- & -- & -- & -- & -- & -- \\
\hline Mortar & Limestone & 71 & -- & -- & 29 & -- & -- & -- & -- & -- & -- & -- & -- & -- & -- \\
\hline Mortar & Redbrick & 56 & -- & 10 & 34 & -- & -- & -- & -- & -- & -- & -- & -- & -- & -- \\
\hline Mortar & Terrazzo & 71 & -- & 17 & 6 & 6 & -- & -- & -- & -- & -- & -- & -- & -- & -- \\
\hline Plaster & Palace & 33 & -- & 44 & 12 & -- & -- & -- & -- & 11 & -- & -- & -- & -- & -- \\
\hline Plaster & Marina & 38 & -- & 21 & 23 & -- & 18 & -- & -- & -- & -- & -- & -- & -- & -- \\
\hline Terrazzo & Balcony & 62 & -- & 16 & -- & -- & -- & -- & -- & 4 & 9 & 4 & 5 & -- & -- \\
\hline
\end{tabular}

Ca: Calcite; Do: Dolomite; Al: Albite; Qu: Quartz; He: Hematite; An: Anhydrite; Ha: Halite; Di: Diopside; Br: Brucite; Ma: Malachite; Gr: Greenalite; Po: Portlandite; Mu: Muscovite; Il: Illite 
FTIR Results: compounds obtained from the XRD analyses were confirmed by the presence of their functional groups when analyzed using FTIR; limestone samples are mainly calcite (figures $12 \& 13$ ). This is emphasized by the presence of the characteristic bands of calcite: broad strong band at $\approx 1427 \mathrm{~cm}^{-1}$ due to $\mathrm{CO}_{3}{ }^{2-}$ stretching vibration, $\mathrm{C}=\mathrm{O}$ stretching band of $\mathrm{CO}_{3}{ }^{2-}$ at $\approx 1799 \mathrm{~cm}^{-1}$ and $\mathrm{O}-\mathrm{C}-\mathrm{O}$ bending band of Carbonate group at $\approx$ $875 \mathrm{~cm}^{-17}$ Small C-H stretching bands in the range between 2924 and $2871 \mathrm{~cm}^{-1}$ are due to organic impurity. FTIR analysis of the redbrick sample from the marina (figure 14); shows that the sample is mainly silicate minerals, bands at 1073,783 and $460 \mathrm{~cm}^{-1}$ confirm this conclusion, bands at 3440 and $1631 \mathrm{~cm}^{-1}$ represent bonded $\mathrm{O}-\mathrm{H}$ stretching vibration and $\mathrm{H}-$ $\mathrm{O}-\mathrm{H}$ bending vibration. The redbrick sample from the palace wall (figure 15); showed the strong broad band at $3426 \mathrm{~cm}^{-1}$ represents bonded $\mathrm{O}-\mathrm{H}$ stretching vibration. The band at $1634 \mathrm{~cm}^{-1}$ is assigned to $\mathrm{H}-\mathrm{O}-\mathrm{H}$ bending vibration. The small stretching band at $1435 \mathrm{~cm}^{-1}$ is due to $\mathrm{CO}_{3}{ }^{2-}$ group indicating the presence of trace amount of calcite in the sample. Bands at 1060, 780 and $461 \mathrm{~cm}^{-1}$ are assigned as Si-O-Si asymmetric, symmetric and bending vibrations respectively of quartz. Small C-H stretching band at $2924 \mathrm{~cm}^{-1}$ is due to an organic impurity. Concerning the mortars; FTIR spectrum of the mortar jointing limestone (figure 16); shows the presence of the characteristic bands of calcite at 1796, 1429 and $874 \mathrm{~cm}^{-1}$ in addition to that of quartz at 1080, 788 and $464 \mathrm{~cm}^{-1}$, while the mortar jointing redbrick (figure 17); showed the vibrations of calcite $\left(\mathrm{CaCO}_{3}\right)$ peaked around 1432, 873 and $712 \mathrm{~cm}^{-1}$ assignable to $\mathrm{CO}_{3}{ }^{2-}$ group. Bands related to quartz and silicates around 1080, 786 and $453 \mathrm{~cm}^{-1}$ are also identified, third mortar sample (Terrazzo mortarfigure 18); shows the presence of a strong broad band around $1430 \mathrm{~cm}^{-1}$ in addition to two bands at 1796 and $875 \mathrm{~cm}^{-1}$ proving the presence of calcite. The spectrum shows also the presence of a very broad band in the range $1082-1053 \mathrm{~cm}^{-1}$ assignable as Si-O stretching plus the two bands at 788 and $465 \mathrm{~cm}^{-1}$. These bands are related to quartz and silicates. Bands at 2929 and $2868 \mathrm{~cm}^{-1}$ are due to an organic impurity. As for plaster; the sample taken from the palace walls (figure 19); shows the same results obtained from the mortar analysis, while the second plaster sample (figure 20); shows the vibrations of calcite, $\mathrm{CaCO}_{3}$, peaked around 1432, 873 and $712 \mathrm{~cm}^{-1}$ assignable to $\mathrm{CO}_{3}{ }^{2-}$ group were identified. FTIR spectrum of the terrazzo sample (figure 21); shows the presence of Si-O stretching bands in the area $1100-900 \mathrm{~cm}^{-1}$ confirming the characterization of silicates. Calcite bands are also present at 1427,1799 and $879 \mathrm{~cm}^{-1}$. The IR bands at 3684 and $3452 \mathrm{~cm}^{-1}$ correspond to $\mathrm{OH}$ frequencies (silanol group, $\mathrm{Si}-\mathrm{O}-\mathrm{H}$ ) while the IR band at $1638 \mathrm{~cm}^{-1}$ represents $\mathrm{H}-\mathrm{O}-\mathrm{H}$ bending vibration of water.

\footnotetext{
${ }^{7}$ Derrick et al., Infrared Spectroscopy, p. 115.
} 


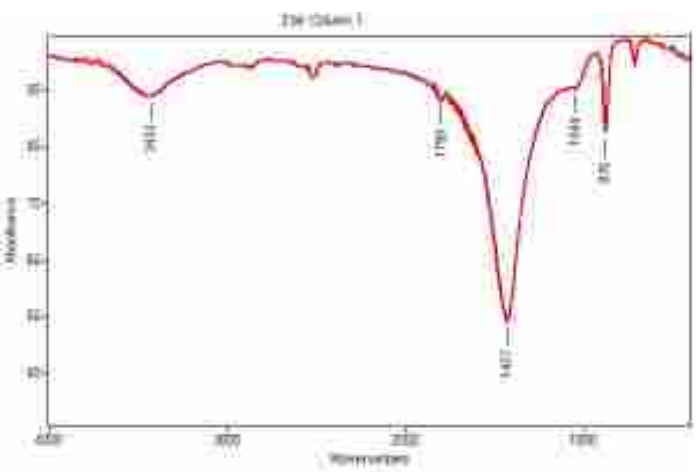

Figure 12: FTIR spectrum of the marina limestone sample

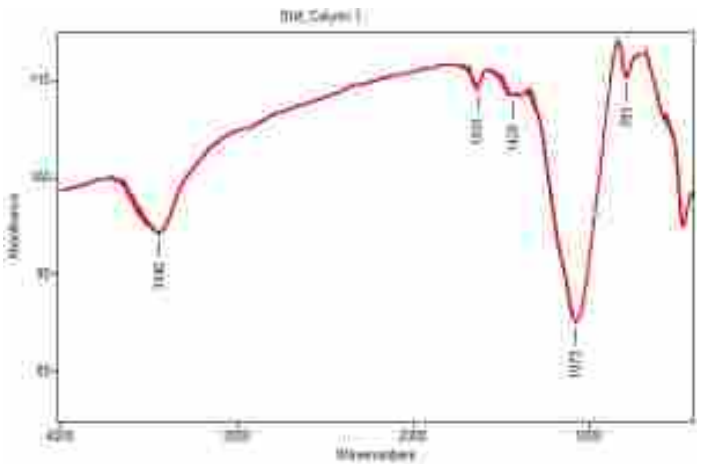

Figure 14: FTIR spectrum of the marina redbrick sample

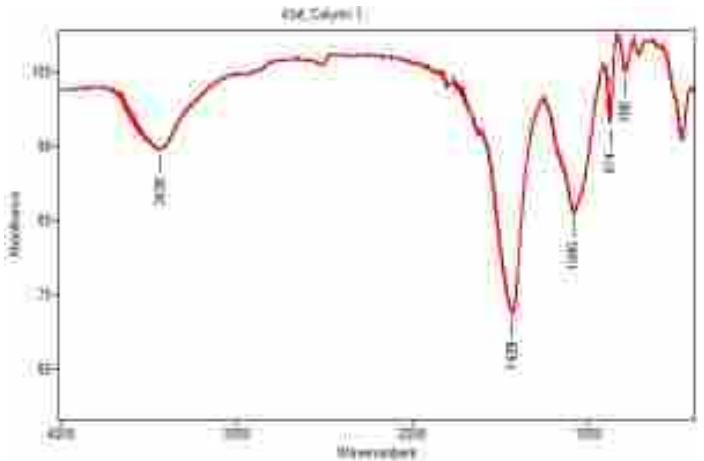

Figure 16: FTIR spectrum of the limestone mortar sample

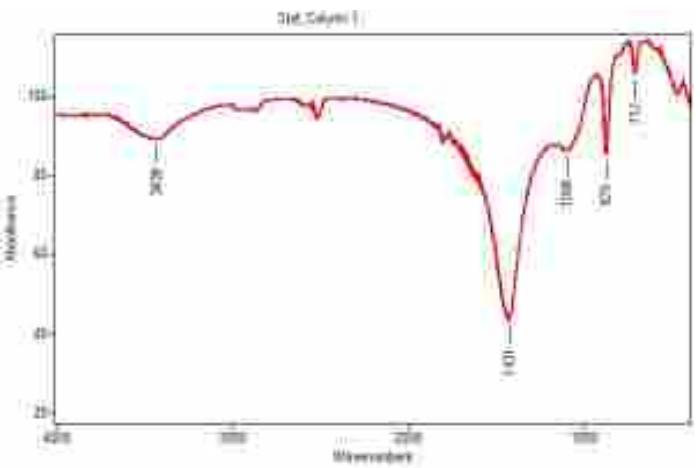

Figure 13: FTIR spectrum of the palace limestone sample

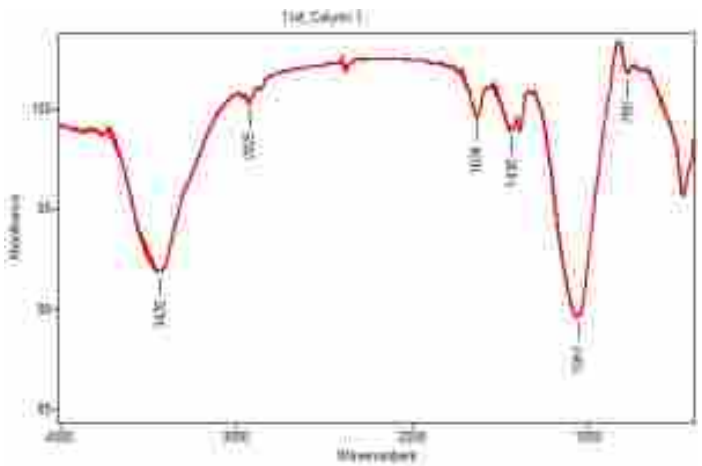

Figure 15: FTIR spectrum of the palace redbrick sample

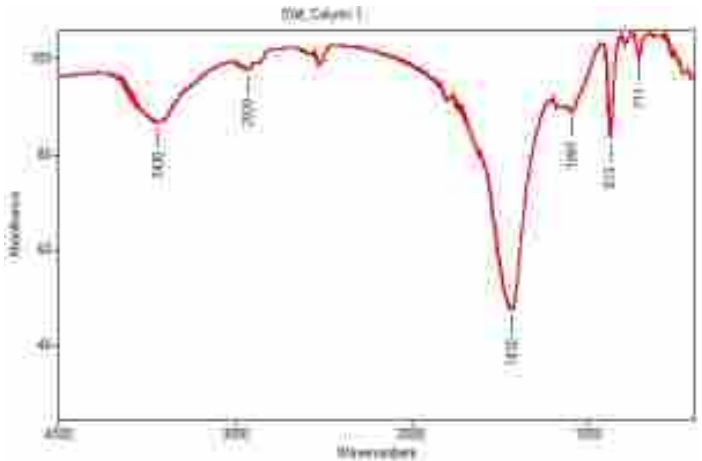

Figure 17: FTIR spectrum of the redbrick mortar sample 


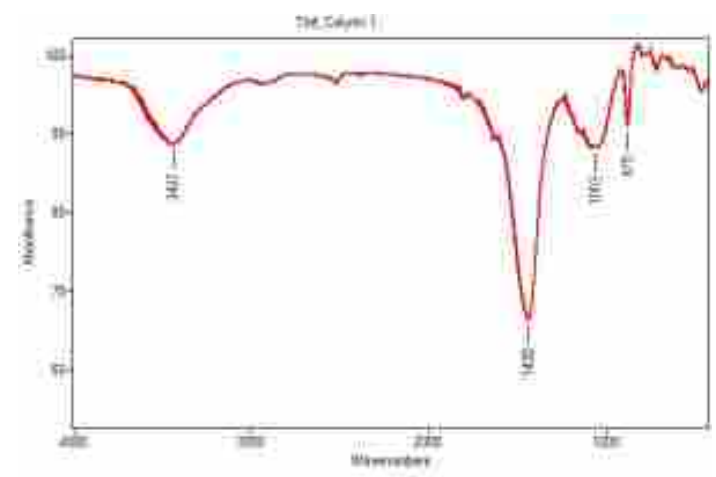

Figure 18: FTIR spectrum of the terrazzo mortar sample

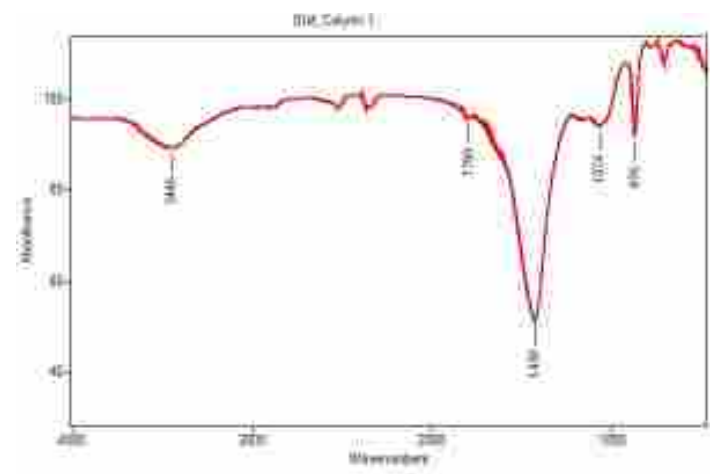

Figure 20: FTIR spectrum of a plaster sample from the marina

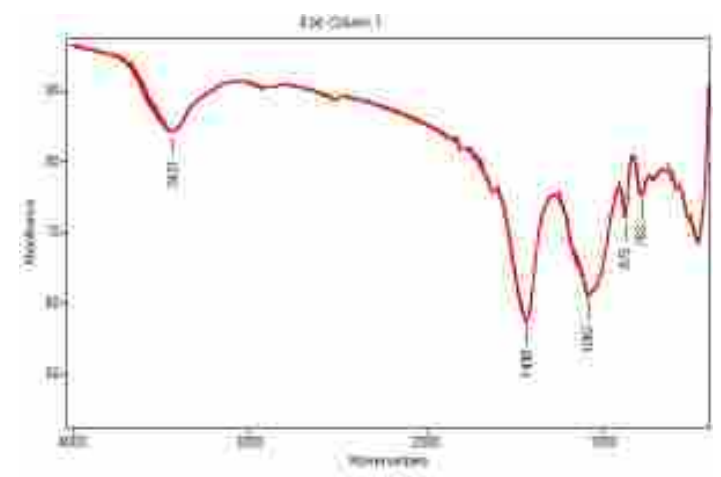

Figure 19: FTIR spectrum of a plaster sample from the palace

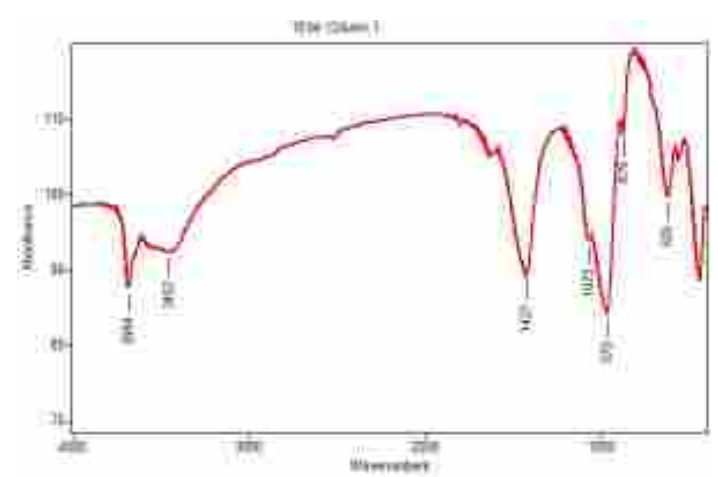

Figure 21: FTIR spectrum of a terrazzo sample from the palace

Nano Treatment Results: Oriented untreated mortar sample was investigated by mean of SEM for comparison (figure 22); the examination proved that the mortar surface loses cohesion, while friability is clear in some points. Voids and gaps are also clearly seen on the mortar surface; these results make it obligatory to start in consolidation procedures.

Nanolime: according to previous authors (addressed in the discussion); it has been mandatory to use water mixed with alcohol in dispersing nanolime. This solvent makes the solution more stable, in addition it provides long-term penetration into the treated building material due to the presence of water, the obtained results from using nanolime in consolidation of cement-lime mortars were disappointing; the SEM investigation has shown a deposited mass of nanolime on the treated surface, in addition; gaps and voids are still unfilled with consolidation material. It was also noticed that the adhesion between nanoparticles is lost and there is no correlation. Nanolime has appeared as divided agglomerates upon the treated surface (figure 23).

\footnotetext{
- 239 - Nano Treatment of Decayed Cement-Lime Mortars from the Edfena Royal Palace
} 

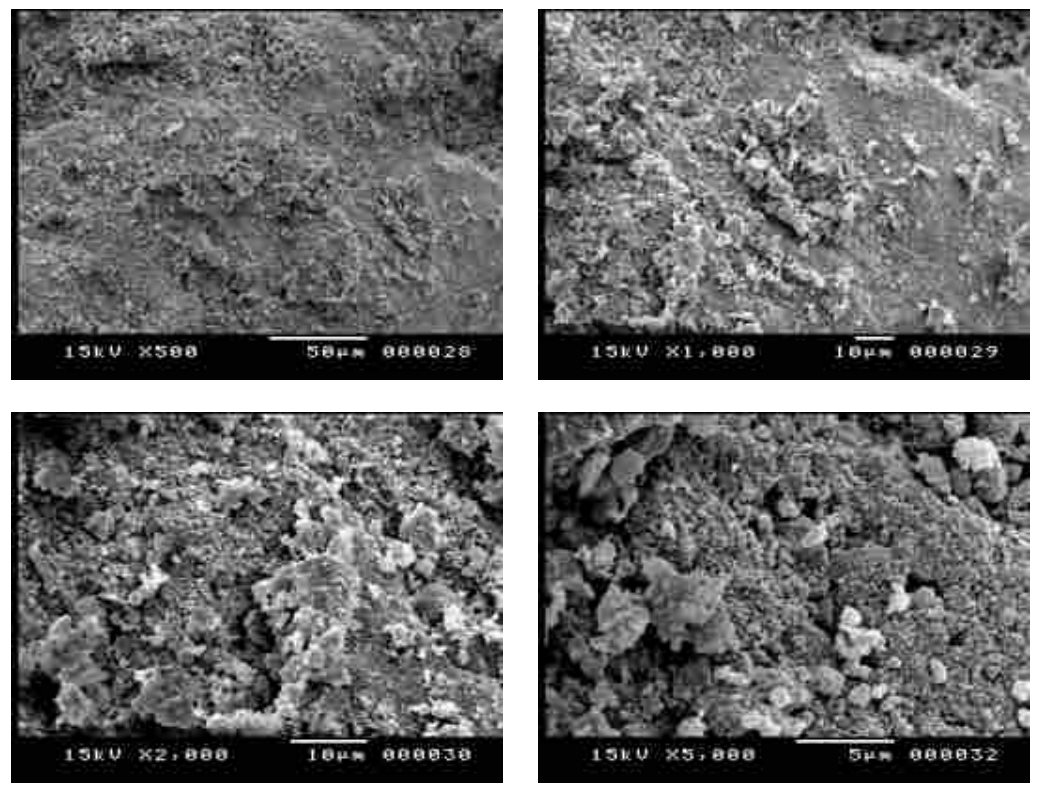

Figure 22: Scanning electron micrographs of the untreated mortar sample
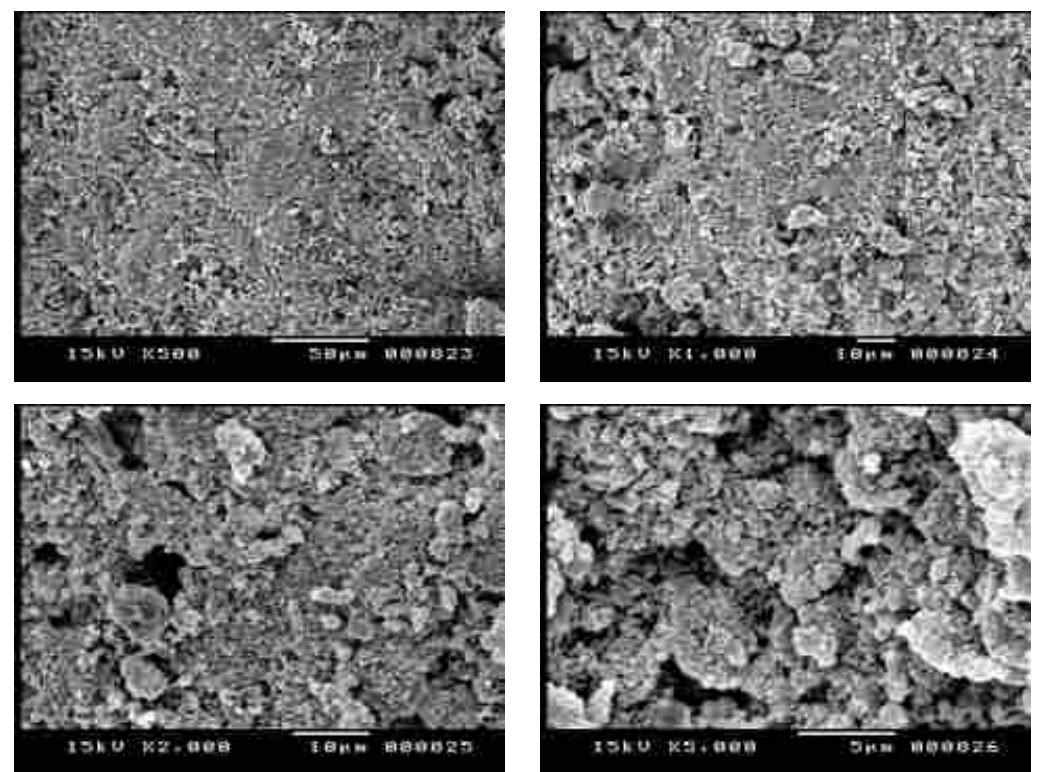

Figure 23: Scanning electron micrographs of the cement-lime mortar treated with nanolime

Nanotitanium: the results obtained from the SEM investigation are propitious (figure 24). Nanotitanium has formed a correlated porous film upon the treated mortar surface; the continuity of that film provides both consolidation and protection. This material can act as a preventive material, due to its antibacterial characteristics. Nanotitanium is an appropriate consolidant for mortars exposed to humidity and invaded by microorganisms.

Nanokaolin: the results provided by the SEM proved that there is some lamina of nanokaolin deposited upon the mortar surface. These separated nanokaolin sheets were obviously detected (figure 25). Some gaps and voids were also detected upon the treated 
mortar surface, thus; nanokaolin didn't provide the optimum desired results from the consolidation process.
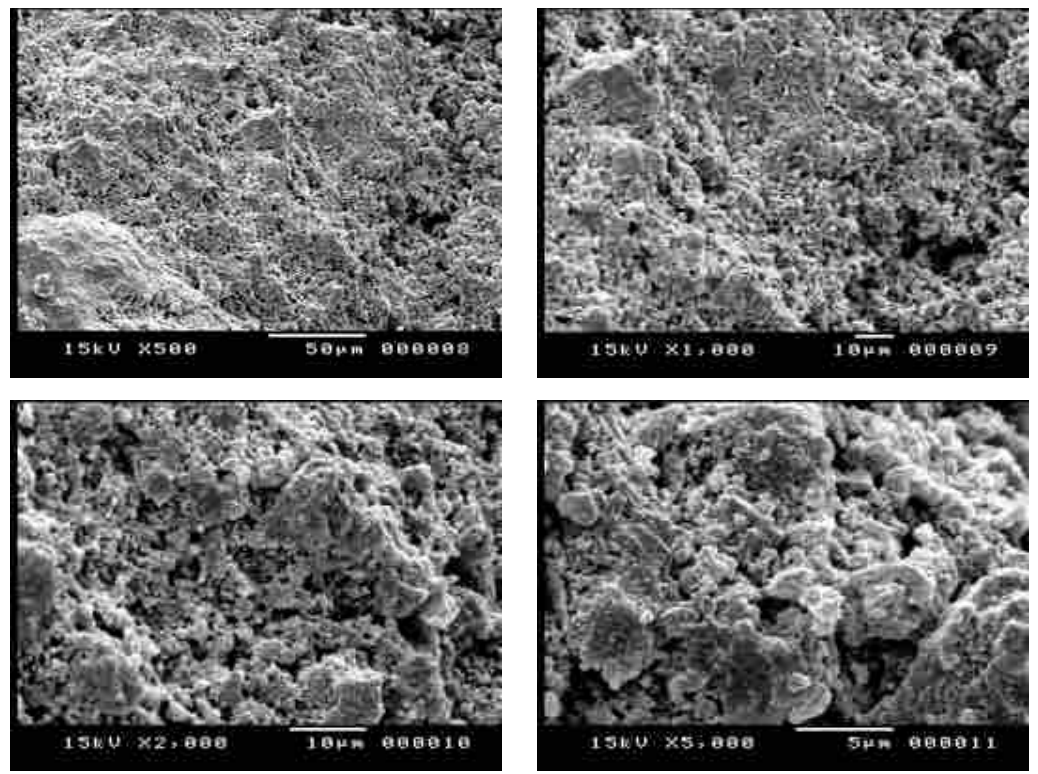

Figure 24: Scanning electron micrographs of the cement-lime mortar treated with nanotitanium
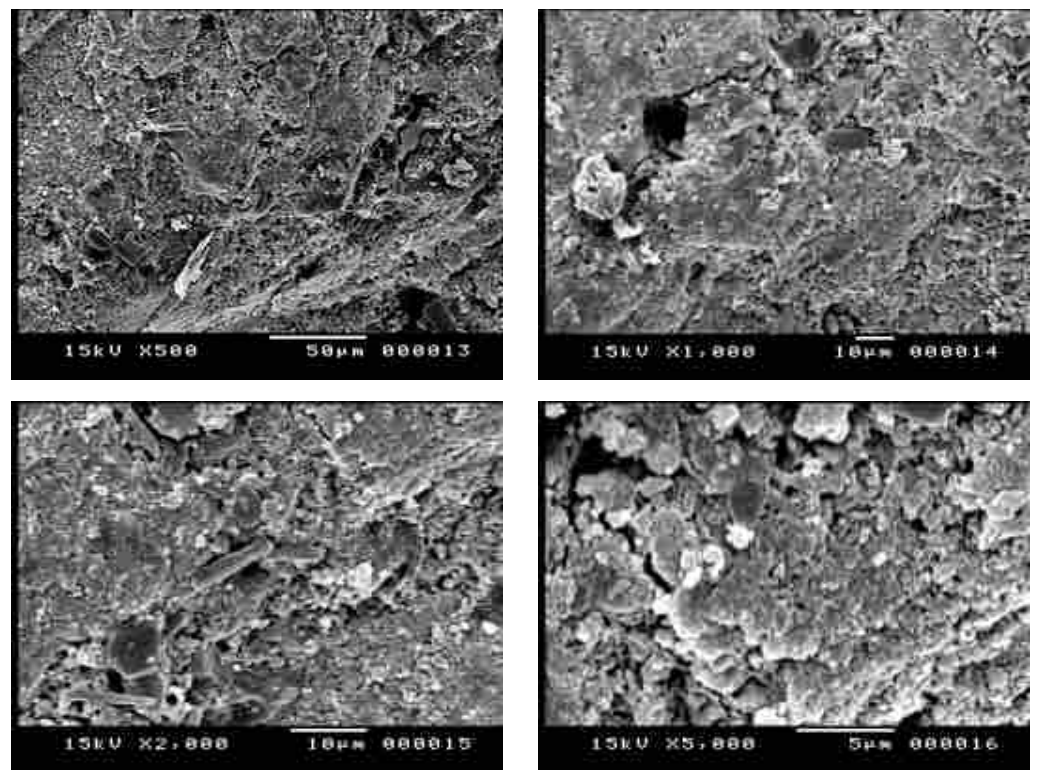

Figure 25: Scanning electron micrographs of the cement-lime mortar treated with nanokaolin

Nanosilica: SEM investigation of the mortar sample treated with nanosilica dispersed in Paraloid proved that; although nanosilica has penetrated into cement-lime mortar, but Paraloid has agglomerated onto the mortar surface (figure 26). It has been also noticed that some nanoparticles were deposited upon the mortar surface, most of the previous studies (addressed in discussion) were achieved on the role of nanosilica in consolidation were related to concrete and modern fresh mortars. This study deals with ancient mortars and proves that nanosilica is not among the recommended consolidants for historical cementlime mortars.

- 241 - Nano Treatment of Decayed Cement-Lime Mortars from the Edfena Royal Palace 
MWCNTs: no evidence till now for the use of multi-walled carbon nanotubes as consolidant. The current study represents the first step in that trend. Polycarboxylate superplasticizer acts as a lubricant and a solvent, based on the data obtained from SEM (figure 27); it has been noticed that there is a sufficient penetration of the consolidant into the treated mortar. Moreover; a correlated porous film has been generated upon the mortar surface. This protective unseen (by naked eye) layer is fundamental for mortar breathability; it also enhances durability and doesn't affect the aesthetical appearance of the treated substrate. Thus; multi-walled carbon nanotubes is one of the recommended consolidants for cement-lime mortars at the royal palace of King Farouk.
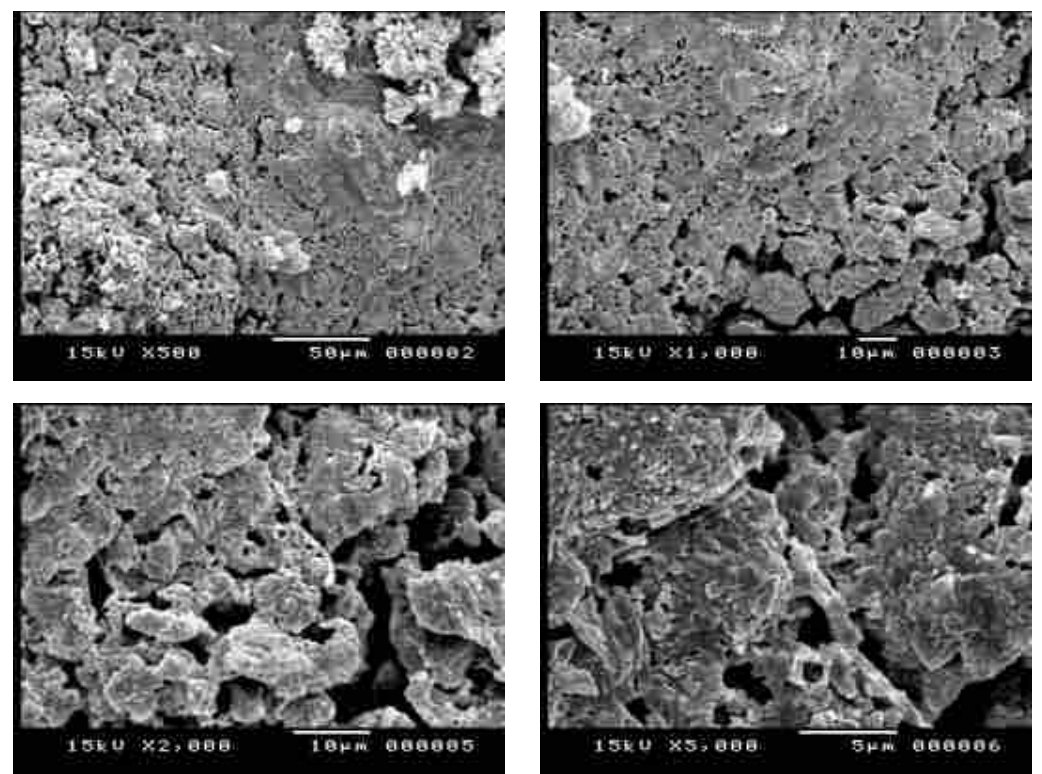

Figure 26: Scanning electron micrographs of the cement-lime mortar treated with nanosilica
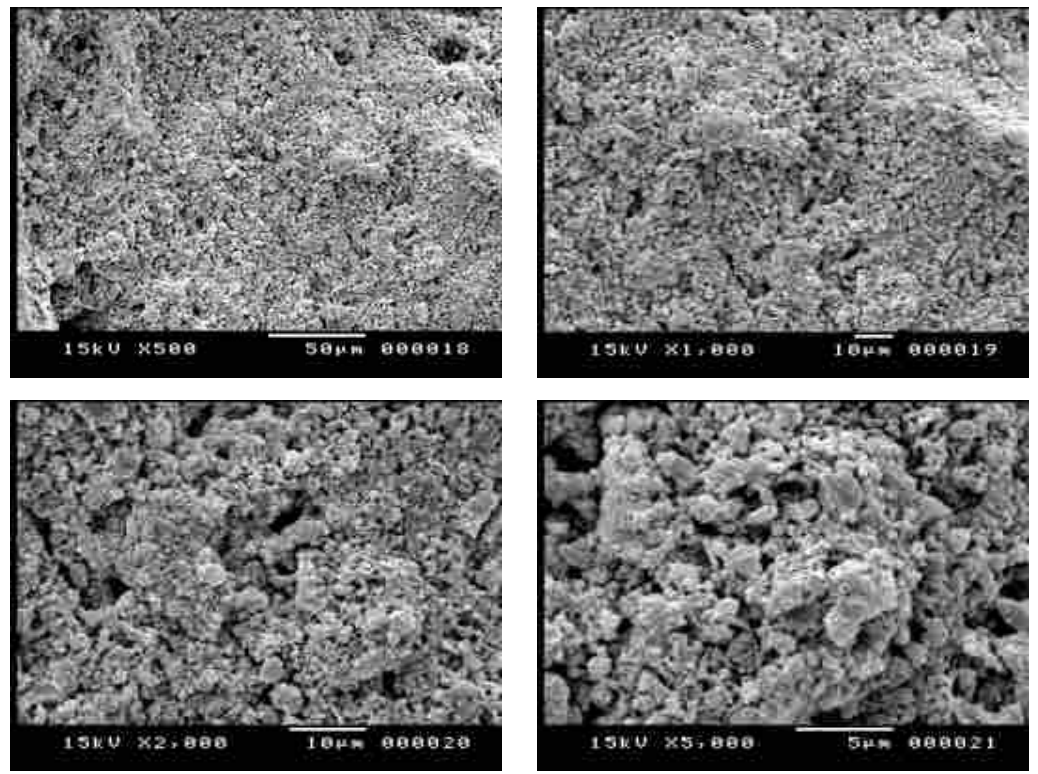

Figure 27: Scanning electron micrographs of the cement-lime mortar treated with multiwalled carbon nanotubes 


\section{DISCUSSION}

Based on the XRD and FTIR results; two different types of limestone were used in the studied palace; calcareous for the marina and dolomitic for the palace itself. It is obvious that the architect used the more durable kind for the marina due to its direct location on the river Nile; and its direct connection to water and other deformation agents. Max limestone quarries; west of Alexandria -Tertiary formations: mainly Eocene but also Paleocene and Pliocene- were the main source of building stones in northern Egypt for millennia, these quarries are distinguished by the presence of dolomite and halite, ${ }^{8}$ halite dissolves at $>76 \%$ $\mathrm{RH}$; while other salts like mirabilite $\left(\mathrm{Na}_{2} \mathrm{SO}_{4} * 10 \mathrm{H}_{2} \mathrm{O}\right)$ and natron $\left(\mathrm{Na}_{2} \mathrm{CO}_{3} * 10 \mathrm{H}_{2} \mathrm{O}\right)$ dissolve at $<50 \% \mathrm{RH}^{9}{ }^{9}$ They are the most common saline minerals in mortars. ${ }^{10}$ Salt weathering by mirabilite is destructive while halite, in contrast, is one of the least damaging salts. ${ }^{11}$ Concerning redbrick; there is no evidence for its use in Egypt before the GrecoRoman era. ${ }^{12}$ Redbrick used in the marina is chromatically and chemically different from those used in the palace walls. Quartz is a basic component during manufacture; while hematite refers to Egyptian soil. The red brick is locally produced. Illite abreast with muscovite was detected in the marina redbrick; precipitation of illite depends strongly on temperature. ${ }^{13}$ It also replaces smectite in shales; illite is indicator for arid climate conditions. It may form by the alteration of muscovite and feldspars under high $\mathrm{pH}$ conditions. ${ }^{14}$ These clays have better binding qualities, exhibit considerable shrinkage and swelling and can absorb more water both through capillary and hygroscopic actions. ${ }^{15}$ The degree of the swelling of such clays depends mainly on the mineralogy and engineering properties of the clay mineral itself; i.e. clay content, clay mineralogy, water content, density, slake durability, degree of consolidation, cementation, compressive strength. ${ }^{16}$ Because of the position of the charge deficiency the illite structure is relatively fixed in its position and the polar ions cannot enter the interlayer space. Hence there is no expansion of the illite molecule. Additionally, the cations which balance the interlayer charge are not exchangeable. ${ }^{17}$ Concerning diopside; Fired bricks usually reveal lack of kaolinite, but contain iron-rich minerals such as hematite and magnesium-rich diopside. ${ }^{18}$ Clays fired at $1000{ }^{\circ} \mathrm{C}$ contains traces of calcium silicates (diopside), this diagnostic mineral form comes from the calcium generated by the breakdown of calcite during firing. Calcite decomposes at $600-8500^{\circ} \mathrm{C}$ in fired clay, and diopside appears at $850-900{ }^{\circ} \mathrm{C} .{ }^{19}$ Diopside is also found in metamorphic rocks developed from high silica dolomites. ${ }^{20}$ Diopside was detected in the fired clay pastes used for ceramic industrial production from many sites in Egypt. ${ }^{21}$ As for mortars; three types were detected: lime mortar (used with limestone blocks), white Portland cement mortar (used with redbrick units) and white Portland cement mortar mixed

\footnotetext{
${ }^{8}$ Harrell and Storemyr, “Ancient Egyptian Quarries”, pp. 7-50.

${ }^{9}$ Yilmaz, "Gypsum/anhydrite", pp. 227-230.

${ }^{10}$ Alves et al., "Characterization of Saline Pollution", pp. 1-10.

${ }^{11}$ Doehne et al., "Damage to Monuments", pp. 37-46.

12 Aston et al., Stone, p. 7.

${ }^{13}$ Milliken, "Late Diagenesis", pp. 159-190.

${ }^{14}$ Dayal and Varma, "Exploration Technique", pp. 65-93.

${ }^{15}$ Millrath et al., "New Approach", 8-20.

${ }^{16}$ Xeidakis et al., Road Construction, pp. 93-101.

${ }^{17}$ Hunnur, Smectite to Illite Transformation, p. 63.

${ }^{18}$ Bell and Böke, "Comparing the Old and New", pp. 107-123.

${ }^{19}$ Pavía and Roundtree, "An Investigation", pp. 221-242.

${ }^{20}$ Dadian et al., "X-Ray Diffraction”, pp. 45-56.

${ }^{21}$ Darweesh et al., "Red bricks from Dakhla", pp. 201-207.
}

- 243 - Nano Treatment of Decayed Cement-Lime Mortars from the Edfena Royal Palace 
with crushed redbrick and pottery (used as bedding layer for terrazzo); albite refers to white Portland cement while hematite refers to crushed aggregates (figure 28).
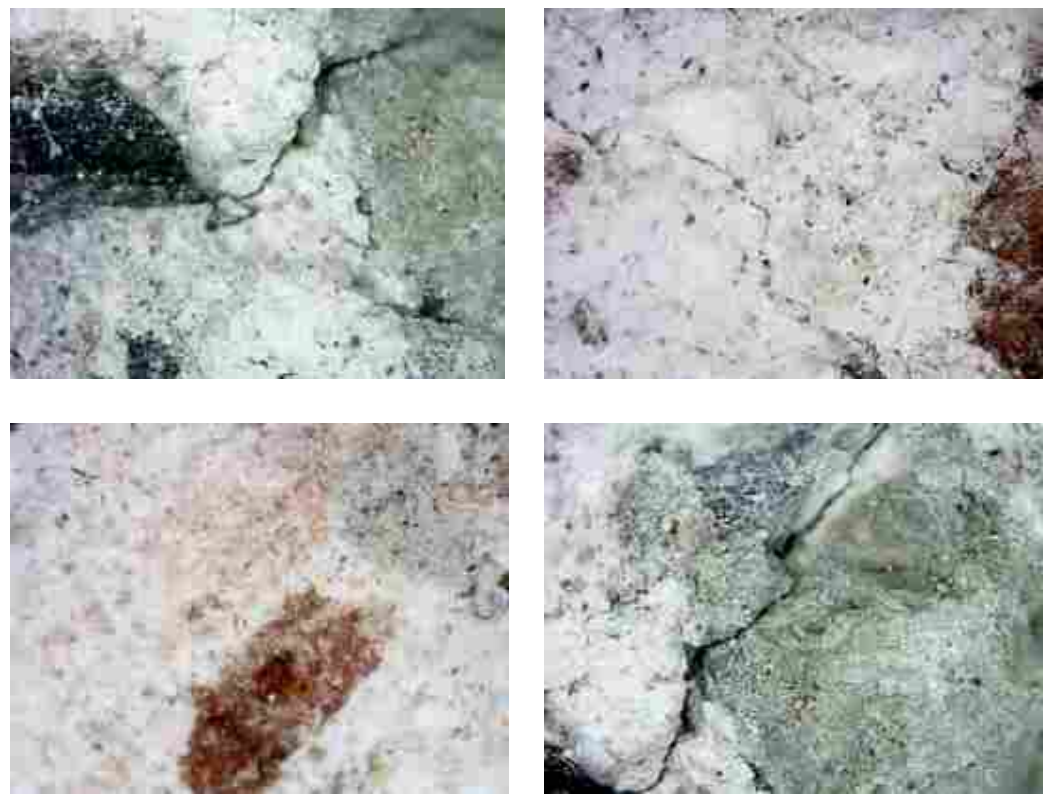

Figure 28: Four different shots taken by light optical digital microscope (500x) showing the aggregates (mainly crushed brick and carbon) added to the studied mortars

Mortars consisting primarily of lime and sand have been used as an integral part of masonry structures for thousands of years. This basic formulation remained unchanged until the advent of Portland cement. ${ }^{22}$ White Portland cement is sensitive to the attack of sulphates and sea water since calcium aluminates react with $\left(\mathrm{SO}_{4}\right)$ Forming ettringite, moreover; cement mortars interact with atmospheric $\left(\mathrm{SO}_{2}\right)$ forming gypsum and ettringite. ${ }^{23}$ Traditional buildings have solid walls; without cavity or damp proof membrane, cement mortars are impervious to damp; and because cement is impermeable, moisture contained within the wall cannot evaporate through the mortar joint; instead it evaporates through the face of the masonry. Soluble salts then crystallize on the surface of the masonry causing premature crumbling of the face. Where a cement-based render is applied, water becomes totally trapped resulting in internal dampness. ${ }^{24}$ High lime mortars are more permeable than denser cement mortars. Salt crystallization within a masonry unit creates pressure that can cause parts of the outer surface to spall off or delaminate. If the mortar does not permit moisture to migrate out of the wall and evaporate; the result will be damage to the masonry units. ${ }^{25}$ External factors such as impermeable coverings also influence drying of masonry; the lower the concentration is, the deeper in walls the salt solution. Thus; weak salt solutions are able to cause remarkable damage in ancient constructions. ${ }^{26}$ This phenomenon is widely visible in the Edfena royal palace, as the only way for the breathability of the building is through the masonry units themselves, thus; redbrick units are more degradable than the mortar joints (figure 29).

\footnotetext{
${ }^{22}$ Toumbakari, Lime-Pozzolan-Cement Grouts, p 88.

${ }^{23}$ Robert and Speweik, "Repointing Mortar Joints", pp. 22.53.

${ }^{24}$ Christensen, Analysis of Mineral Salts, p.39.

${ }^{25}$ Robert and Speweik, "Repointing Mortar Joints", pp. 22.53.

${ }^{26}$ Gonçalves et al., "Drying of Salt”, pp. 293-302.
} 

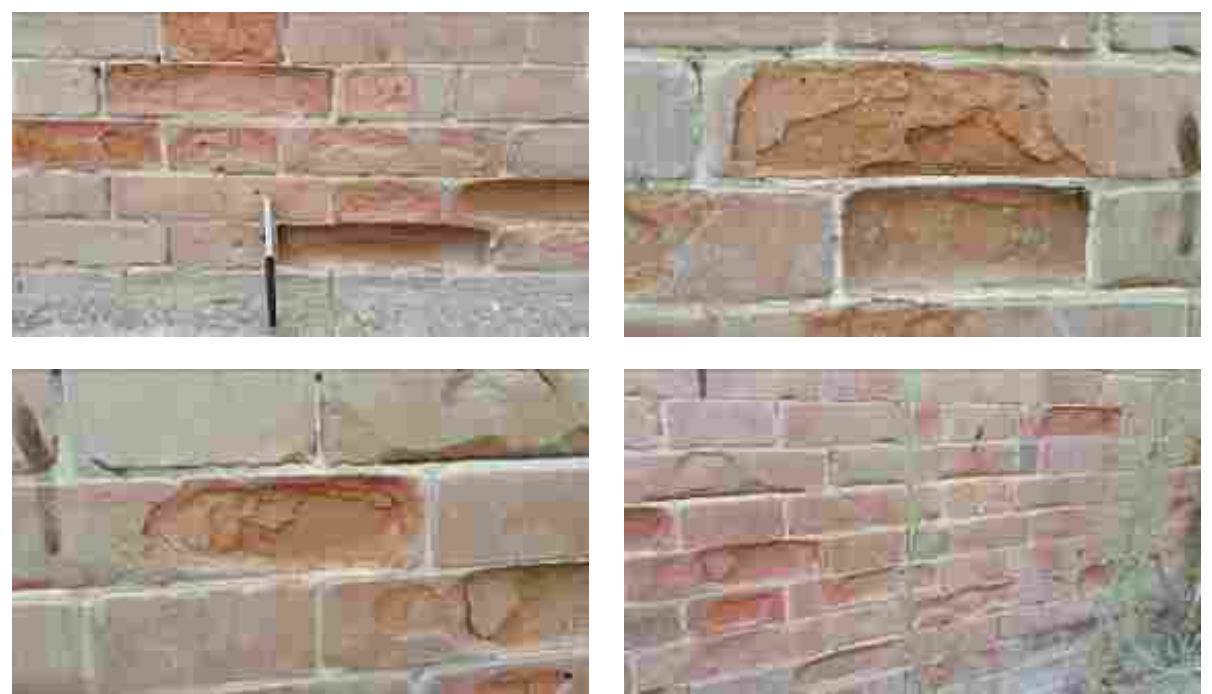

Figure 29: Shows the effect of soluble salts in conjunction with cement mortars and vegetation on the palace walls

The examination of plaster; elucidated the use of white cement in the palace and the marina, anhydrite was detected in the ornamentations analyzed from the marina, geologically; gypsum precipitates out first, followed by anhydrite deposits, in the presence of groundwater anhydrite can turn into gypsum to some 15 to 40 meters depth. ${ }^{27}$ More anhydrite is a naturally deposited mineral. It can't be declared that it is here as a result of gypsum dehydration; it may emphasize that no changes happened, and the first used filler was anhydrite. The alteration of gypsum into anhydrite requires millennia of heat and pressure. Many archaeological sites don't provide these circumstances; ancient builders may sought anhydrite as it is whiter and lighter than gypsum.

Terrazzo is a composite material consists of crushed limestone, quartz and pieces of granite, marble or glass cemented together in a mortar base. ${ }^{28}$ This technique dates back to the $18^{\text {th }}$ century in Italy and is derived from the "Pavimento alla Veneziana" technique, it is also related to the "Seminato" technique; while large pieces of marble are tossed into cement tiles and then polished. ${ }^{29}$ Detection of portlandite and brucite is due to many factors, amongst; defects in the slaking process of lime, the final product could contain some crystalline $\mathrm{CaO}$ and $\mathrm{MgO}$, the hydration reaction of $\mathrm{CaO}$ and $\mathrm{MgO}$ (to give portlandite and brucite) are expansive; causing cracks problems and break down of mortars. ${ }^{30}$ Portlandite and brucite are normal components in ordinary Portland cement and white Portland cement; but their presence in our case study whether in mortars or terrazzo is indicator for a long-term thermal impact. ${ }^{31}$ Terrazzo was prepared on the base of white Portland cement and dyed in order to obtain the green color effect; malachite mixed with greenalite was used as a pigment material; no previous evidences for this mixture in Egypt, moreover; no evidence for using malachite in the pharaonic wall paintings; this pigment became common since the Greco-Roman era; greenalite is a member of the serpentine clay group, it is supposed that it has been used here to get a light green color (figure 30).

\footnotetext{
${ }^{27}$ Charola et al., "Gypsum”, pp. 339-352.

${ }^{28}$ Jester, Twentieth-Century, p. 124.

${ }^{29}$ Bagnara, Construction and Restoration, p. 31.

${ }^{30}$ Palomo et al., Historic Mortars, p. 17.

${ }^{31}$ Bartz and Martusewicz, "Terrazzo Floor”, pp. 1-13.
}

- 245 - $\mid$ Nano Treatment of Decayed Cement-Lime Mortars from the Edfena Royal Palace 

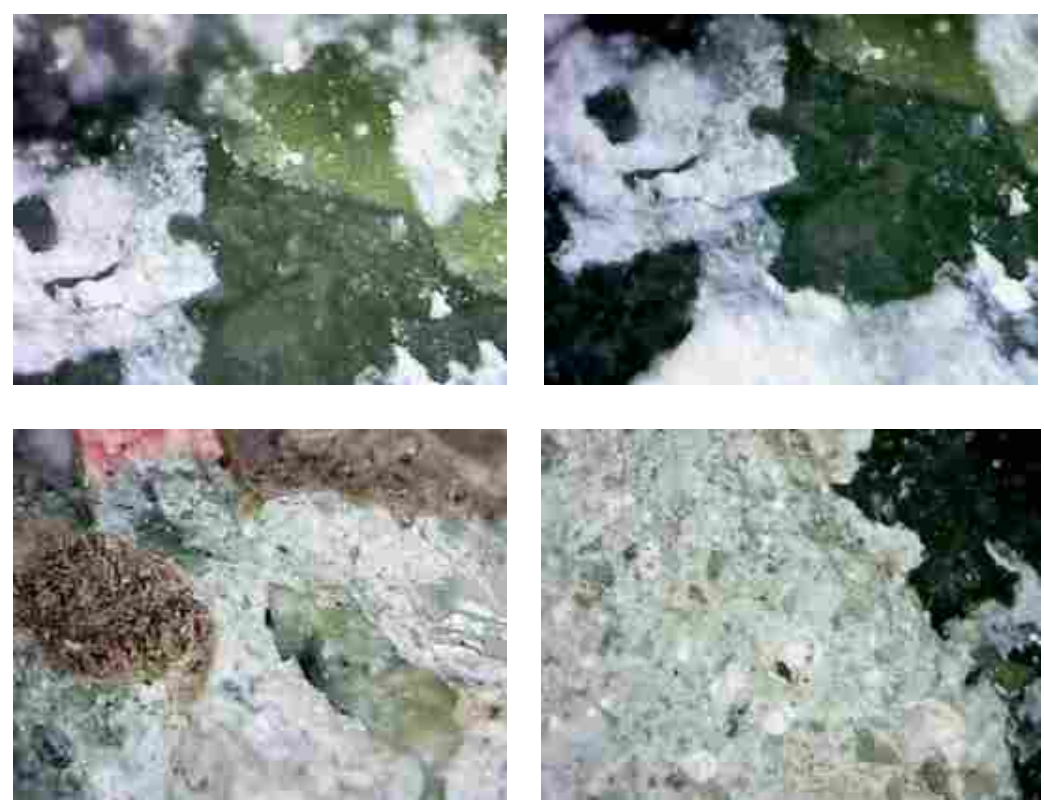

Figure 30: The terrazzo sample under light optical microscope (500x)

Consolidation treatment should guarantee three fundamental requirements: effectiveness, compatibility and long-term durability. ${ }^{32}$ Nanolime (NL) can be used to restore the transformation of calcium carbonate into gypsum in wall paintings, it interacts with carbon dioxide to reform calcium carbonate and replace the degraded ligand; carbonation process is faster in case of nano than in case of traditional microsize leading to a quick consolidation effect. ${ }^{33}$ Baglioni et al., $2006^{34}$ noted that lime-water can be used as consolidant; but its efficacy is limited by the poor solubility of calcium hydroxide in water, sedimentation rate is too fast, particle size is too large in addition to producing white glazing over painted surfaces, while Otero et al., $2017^{35}$ declared that nanolime appears to be an effective consolidant for superficial consolidation, but when an in-depth consolidation is needed, the results vary significantly due to nanolime concentration, nature of solvent, $\mathrm{CO}_{2}$ exposure and relative humidity. In case the surface is non-absorptive, the suspension remains near to the surface or on top of it; while lime particles create white veil on the surface ${ }^{36}$ this may also happen due to back migration of the nanoparticles during drying $^{37}$, according to Musacchi and Gonçalves $2014 ;{ }^{38}$ after the application of nanolime, the surface of lime mortars becomes whitish due to the evaporation of alcohol. This defect has been avoided by the addition of water into alcohol.

Nano-titanium (NT) enhances UV stabilization, strength, and antibacterial activity to the treated mortars, mechanical properties of the composite increase when nano-titanium is added, ${ }^{39}$ the inclusion of NT into the matrix (in case of fresh mortars) reduces the percentage of water absorption, permeability and chloride penetration; this may depend on

\footnotetext{
${ }^{32}$ Gryffroy, Nanolime Consolidation, p. 47.

${ }^{33}$ Rodorico et al., "Nanoparticles", pp. 74-82; Borsoi, Nanostructured, p. 29.

${ }^{34}$ Baglioni et al., "The Maya Site", pp. 162-169.

${ }^{35}$ Otero et al., "An Overview of Nanolime”, pp. 71-78.

${ }^{36}$ Vojtechovsky and Bayer, International workshop, p. 16.

${ }^{37}$ Borsoi et al., "Optimization of Nanolime", pp. 1-10.

${ }^{38}$ Musacchi and Gonçalves, Influence of Nano-Lime, p. 19.

${ }^{39}$ Deniz et al., "Nanocomposites", pp. 364-369.
} 
factors such as curing conditions, pozzolan type \& content, chemical admixture and nanoparticle size ${ }^{40}$ nano-titanium changes the physical properties of mortars through closing the pores and increasing the density, ${ }^{41}$ nano-titanium was also added to mortars in order to reduce the pollutant concentration in indoor air, contributing to a more sustainable construction, ${ }^{42}$ the mechanical characterization indicated that nano-titanium enhanced carbonation and hydration of mortar mixtures, the hydrophilicity of nano-titanium improved also the humidity retention into mortars, facilitating thus the carbonation and hydration processes. ${ }^{43}$ The current case study recommends nanotitanium as an optimum consolidant for ancient cement-lime mortars.

Nanokaolin (NK) can act as a cheap and effective reinforcing agent for different materials. The incorporation of nanokaolin gives maximum improvement in mechanical properties ${ }^{44}$. Nano-kaolin has been proven as an excellent material that can be used to enhance the properties of kaolinite clay. This can prevent swelling and give stability to clay minerals. ${ }^{45}$ For mortars; nano-kaolin reduces water penetration and alkali silica reaction by acting as filler and increasing hydration process while fewer voids are created. ${ }^{46} \mathrm{NK}$ is recommended with freshly prepared alternative repointing mortars or grouts; it didn't prove the same advantages as a consolidant.

Nanosilica (NS) improves the mechanical properties of mortars through affecting the compressive strength and durability properties. It has been noticed that nanosilica also reduces the amount of portlandite in cement mortars. ${ }^{47}$ The optimum quantity of nano-silica to be used is still contradictory; but the influence on water amount required in the mixture was observed when nano-silica was incorporated into the mortars in fresh state. ${ }^{48}$ Because nanosilica always decreases the workability of mortars; it is used as a combination with water or superplasticizers. Nanosilica affects also hydration and has a fundamental impact on the density and the voids. ${ }^{49}$ Most of the previous studies note that; nano-silica is used as an additive for the cementitious materials to improve the mechanical and durability properties due to its physio-chemical reactive characteristics. ${ }^{50}$ Mortar compressive strength increases with the addition of $6 \% \mathrm{NS}$, while tensile strength increases with $8 \% \mathrm{NS}$ under optimum conditions at 28 days age, ${ }^{51}$ Ayad and Said $2018^{52}$ noted that the use of the small particle size of NS helped to reduce the amount of small pores in mortars, NS also reduces the amount of calcium hydroxide in the mixture, and enhances the pozzolanic reaction. The main disadvantage of NS is the aesthetical change; NS gives the treated mortars some shine, ${ }^{53}$ nanosilica was used individually and mixed with polycarboxylate superplasticizer in order to improve the performance of lime mortars. ${ }^{54}$ The experimental study assured the previous conclusion; due to the deposition of nanoparticles upon the treated surface.

\footnotetext{
${ }^{40}$ Rashad, “A Synopsis”, pp. 72-88.

${ }^{41}$ Khalafalla et al., "Improving", pp. 663-681.

${ }^{42}$ Lucas et al., "Incorporation of Titanium", pp. 112-120.

${ }^{43}$ Maravelaki et al., "Characterization", pp. 66-73.

${ }^{44}$ Anjana and George, "Reinforcing Effect", pp.868-872.

${ }^{45}$ Zainuddin et al., "Study of Nano Koalinite", pp. 1-15.

${ }^{46}$ Fadzil et al., "Characterization of Kaolin", pp. 1-9.

${ }^{47}$ Isfahani et al., "Effects of Nanosilica", pp. 1-16.

${ }^{48}$ Aggarwal et al., "Use of Nano-Silica", pp. 1-11.

${ }^{49}$ Bianchi, Application of Nano-Silica, p. 68.

${ }^{50}$ Mohammed et al., “A Review on Nano-Silica”, pp. 1-4.

${ }^{51}$ Saleh et al.,"Characterization of Nano-Silica", pp.1123-1133.

${ }^{52}$ Ayad and Said, "Using Colloidal Nano Silica", pp. 82-90.

${ }^{53}$ Musacchi and Gonçalves, Influence of Nano-Lime, p. 44.

${ }^{54}$ Fernández and Alvarez, "Influence of Nanosilica", pp. 12-24.
}

- 247 - Nano Treatment of Decayed Cement-Lime Mortars from the Edfena Royal Palace 
Carbon nanotubes (CNTs) are derived from rolled graphene planes, CNTs exist as single (SWCNTs), and multi-walled (MWCNTs) structures. ${ }^{55}$ Defects in the atomic CNTs structure play an important role for their mechanical properties, as well as their chemical reactivity and functions, these defects may occur during synthesis or after treatment, ${ }^{56}$ Carbon nanotubes have light weight, large flexibility and high mechanical strength, their small size and low dimension are responsible for their unique properties. ${ }^{57}$ Carbon nanotubes in particular have been of interest because they have shown some similarities to asbestos in shape and fibers. ${ }^{58}$ Carbon nanotubes are highly recommended to be used as reinforcement for alternative mortars and grouts, multi-walled carbon nanotubes dispersed in polycarboxylate superplasticizer; have been used in laboratory experiments for generating a "smart mortar" for conservation purposes of marbles at the Greek acropolis. ${ }^{59}$ Although it's success as a consolidant, but further studies are needed regarding other types of historical mortars and plasters.

\section{CONCLUSION}

This article makes it clear that manufacturing defects, improper building materials and saline salts are the most common degradation factors affecting the building materials at the royal palace of king Farouk at Edfena, Rosetta, Egypt. Calcareous and dolomitic lime stone were used in building; two locally produced kinds of redbrick were also used. Mortars are lime and Portland white cement, while plasters in the palace is a mixture of white Portland cement and lime, plaster in the marina is a mixture of lime, white Portland cement and anhydrite. Pigment material in the green terrazzo is a mix of malachite and greenalite; portlandite abreast with brucite were found in the plaster and mortar. This study detects for the first time the mix of malachite and greenalite to gain light green pigment. Unlike the previous studies; this study is assessing multi-walled carbon nanotubes as a consolidant for ancient cement-lime mortars, this study also declaring that nanotitanium is among the most appropriate consolidants for the current case study, it is ideal for mortars exposed to humidity and invaded by microorganisms.

\footnotetext{
${ }^{55}$ Pandey and Dahiya, "Carbon nanotubes", pp. 15-21.

${ }^{56}$ Jensen et al., Carbon Nanotubes, p. 17.

${ }^{57}$ Kaushik and Majumder, "Carbon Nanotube", pp. 17-37.

${ }^{58}$ Allhoff et al., what is Nanotechnology, p. 63.

${ }^{59}$ Metaxa et al., "Carbon Nanotube Reinforced Mortar”, pp. 2833-2840.
} 


\section{REFERENCES}

Abouseif (Doris Bahrins); Islamic Architecture in Cairo: An Introduction, American University Press, Cairo, 1989.

Aggarwal (Paratibha), Singh (Rahul), Aggarwal (Yogesh), "Use of Nano-Silica in Cement Based Materials - A Review", Civil \& Environmental Engineering 2 (2015), pp. 1-11.

Allhoff (Fritz), Lin (Patrick), Moore (Daniel), what is Nanotechnology and why does it Matter? from Science to Ethics, Blackwell Publishing, John Wiley \& Sons Ltd, London, 2010.

Alves (C.A.S.), Braga (S.M.A.), Trancoso (A.), "Characterization of Saline Pollution Affecting the Angra do Heroismo Cathedral, a Trachytic Monument of Terceira Island (Azores - Portugal)", Ninth Annual V. M. Goldschmidt Conference, Portugal, 2005, pp. 1-10.

Anjana (R), George (K.E), "Reinforcing Effect of Nano Kaolin Clay on PP/HDPE Blends", International Journal of Engineering Research and Applications (IJERA) 2 (4), 2012, pp.868-872. Aston (Barbara), Harrel (James), Shaw (Ian), "Stone", in Ancient Egyptian Materials and Technology, (Nicholson, P.T., and Shaw, I., Eds.,), Cambridge University Press, 1st ed., London, UK, 2001.

Ayad (Achraf), Said (Aly), "Using Colloidal Nano Silica to Enhance the Performance of Cementitious Mortars", Open Journal of Civil Engineering 8 (2018), pp. 82-90.

Baglioni (Piero), Vargas (Ramón), Chelazzi (David), Gonzàlez (Marinés), Desprat (Alice) Giorgi (Rodorico), "The Maya Site of Calakmul: In Situ Preservation of Wall Paintings and Limestone Using Nanotechnology", Studies in Conservation 51 (2), 2006, pp. 162-169.

Bagnara (Joseph), Construction and Restoration of Terrazzo Floors, International Specialized Skills Institute, Australia, 2009.

Bartz (Wojciech), Martusewicz (Jacek), "Terrazzo Floor from the Jewish Historical Institute in Warsaw - Mineralogical Characterization, Conservation and Impact of Fire", Geoscience Records 1 (4), 2017, pp. 1-13.

Bell (Jonathan), Böke (Hasan), "Comparing the Old and New: Traditional Building Materials and the Uch Monument Complex, Pakistan”, Conservation and Management of Archaeological Sites 12 (2), 2010, pp. 107-123.

Bianchi (Quercia), Application of Nano-Silica in Concrete, PhD Thesis, Eindhoven University of Technology, the Netherlands, 2014.

Borsoi (Giovanni), Nanostructured Lime-Based Materials for the Conservation of Calcareous Substrates, Faculty of Architecture and the Built Environment, Delft University of Technology, Netherlands 2017; ISSN 2212-3202.

Borsoi (Giovanni), Lubelli (Barbara), van Hees (Rob), Veiga (Rosario), Silva (Antonio), "Optimization of Nanolime Solvent for the Consolidation of Coarse Porous Limestone", Applied Physics A, Materials Science and Processing, Springer, 2016, pp. 1-10.

Burgoyne (Michael), Mamluk Jerusalem: An Architectural Study, Published on behalf of the British School of Architecture in Jerusalem, by the World of Islamic Festival Trust, 1987, pp. 53- 54.

Charola (A.E.), Puhringer (J.), Steiger (M.), "Gypsum: a Review of its Role in the Deterioration of Building Materials", Journal of Environmental Geology 52 (2007), pp. 339-352.

Cortese (Dalia), "The Nile: Its role in the Fortunes and Misfortunes of the Fatimid Dynasty During its Rule of Egypt (969-1171)", History Compass 13 (1), 2015, pp. 20-29.

Christensen (M.C.), Analysis of Mineral Salts from Monuments by Infra-Red Spectroscopy, The Royal Danish Academy of Fine Arts, School of Conservation, Copenhagen, Denmark 1995.

Creswell, K.A.C., The Muslim Architecture of Egypt, Part II, Ayyubids and Early Bahrite Mamluk, 1959, pp. 135-138.

Dadian (Hossein Sarhaddi), Ramli (Zuliskandar), Abdul Rahman (Nik Hassan Shuhaimi Nik), Mehrafarin (Reza), "X-Ray Diffraction and X-Ray Fluorescence Analysis of Pottery Shards From New Archaeological Survey in South Region Of Sistan, Iran", Mediterranean Archaeology and Archaeometry 15 (3), 2015, pp. 45-56.

Darweesh (H.H.M.), Awad (H.M.), Tawfik (A.), "Red bricks from Dakhla Formation Clay-Tushka Area- Incorporated with Some Industrial Waste by-Products", Journal of Industrial Ceramic 31 (3), 2011, pp. 201-207.

\footnotetext{
- 249 - Nano Treatment of Decayed Cement-Lime Mortars from the Edfena Royal Palace
} 
Dayal (A.M.), Varma (A.K.), "Exploration Technique", in Shale Gas: Exploration and Environmental and Economic Impacts, ScienceDirect, 2017, pp. 65-93.

Deniz (Aydemir), Gulsen (Uzun), Havva (Gumuş), Sonnur (Yildiz), Sultan (Gumuş), Timucin (Bardak), Gokhan (Gunduz), "Nanocomposites of Polypropylene/Nano Titanium Dioxide: Effect of Loading Rates of Nano Titanium Dioxide", Materials Science (Meď̌iagotyra) 22 (3), 2016, pp. 364369.

Derrick (M.R.), Stulik (D.), Landry (J.M.), Infrared Spectroscopy in Conservation Science, The Getty Conservation Institute, Los Angeles, 1999.

Doehne (E.), Selwitz (C.), Carson (D.), de Tagle (A.), "Damage to Monuments from the Crystallization of Mirabilite, Thenardite and Halite: Mechanisms, Environment, and Preventive Possilbilities", Eleventh Annual V. M. Goldschmidt Conference, U.S.A, 2001, pp. 37-46.

Fadzil (M.A.), Nurhasri (M.S.), Norliyati (M.A.), Hamidah (M.S.), Ibrahim (M.H.), Assrul (R. Z.), "Characterization of Kaolin as Nano Material for High Quality Construction", MATEC Web of Conferences 103 (2017), pp. 1-9.

Fernández (J.M), Alvarez (J.I), "Influence of Nanosilica and a Polycarboxylate Ether Superplasticizer on the Performance of Lime Mortars", Cement and Concrete Research 43 (2013), pp. 12-24.

Giorgi (Rodorico), Ambrosi (Moira), Toccafondi (Nicola), Baglioni (Piero), "Nanoparticles for Cultural Heritage Conservation: Calcium and Barium Hydroxide Nanoparticles for Wall Painting Consolidation", Chemistry a European Journal 16 (2010), pp. 74-82.

Gonçalves (Teresa Diaz), Pel (Leo), Rodrigues (Jose' Delgado), "Drying of Salt-Contaminated Masonry: MRI Laboratory Monitoring”, Journal of Environmental Geology 52 (2007), pp. 293-302.

Gryffroy (Jasper), Nanolime Consolidation of Porous Limestones: Influence on the Pore Network, Durability and Weathering Behavior, Master Thesis, Ghent University, Belgium, 2017.

Harrell (J.A.), Storemyr (P.), “Ancient Egyptian Quarries: An Illustrated Overview", In Abu-Jaber, N., Bloxam, E.G., Degryse, P., and Heldal, T., (eds.) QuarryScapes: Ancient Stone Quarry Landscapes in the Eastern Mediterranean, Geological Survey of Norway, Special Publication 12 (2009), pp. 7-50.

Hsu (Sh.), Infrared Spectroscopy, Handbook of Instrumental Techniques for Analytical Chemistry, USA, 2000.

Hunnur (A.T.), Smectite to Illite Transformation: Relevance to Pore Pressure in the Subsurface, Masc., Thesis, Mewbourne School of Petroleum and Geological Engineering, University of Oklahoma, USA, 2006.

Isfahani (Forood), Redaelli (Elena), Lollini (Federica), Li (Weiwen), Bertolini (Luca), "Effects of Nanosilica on Compressive Strength and Durability Properties of Concrete with Different Water to Binder Ratios", Advances in Materials Science and Engineering (2016), pp. 1-16.

JCPDS, Jaint Committee on Powder Diffraction Standards, Index to the Powder Diffraction File, American Society for Testing and Materials, Pennsylvania, 1967.

Jensen (Keld), Bøgelund (Jesper), Jackson (Petra), Jacobsen (Nicklas), Birkedal (Renie), Clausen (Per), Saber (Anne), Wallin (Håkan), Vogel (Ulla), Carbon Nanotubes: Types, Products, Market, and Provi-Sional Assessment of the Associated Risks to Man and the Environment, The Danish Environmental Protection Agency, Denmark, 2015.

Jester (Thomas), Twentieth-Century Building Materials History and Conservation, Getty Conservation Institute, Los Angles, 2014.

Kaushik (B.K.), Majumder (M.K.), "Carbon Nanotube: Properties and Applications, in Carbon Nanotube Based VLSI Interconnects”, Applied Sciences and Technology, SpringerBriefs (2015), pp. 17-37.

Khalafalla (Mohamed), Hodhod (Osama), Adam (Ihab), "Improving the Mechanical and Durability Properties of Cement Mortar by Nano Titanium", Journal of Engineering Sciences 43 (5), 2015, pp. 663-681.

Lucas (S.S.), Ferreira (V.M.), de Aguiar (Barroso), "Incorporation of Titanium Dioxide Nanoparticles in Mortars, Influence of Microstructure in the Hardened State Properties and Photocatalytic Activity", Cement and Concrete Research 43 (2013), pp. 112-120.

Maravelaki (N.), Lionakis (E.), Kapridaki (C.), Agioutantis (Z.), Verganelaki (A.), Perdikatsis (V.), "Characterization of Hydraulic Mortars Containing Nano-Titania for Restoration Applications", 12th 
International Congress on the Deterioration and Conservation of Stone, Columbia University, New York, 2012.

Metaxa (Z.S.), Pasiou (E.D.), Dakanali (I.), Stavrakas (I.), Triantis (D.), Kourkoulis (S.K.), "Carbon Nanotube Reinforced Mortar as A Sensor to Monitor the Structural Integrity of Restored Marble Epistyles Under Shear", $21^{\text {st }}$ European Conference on Fracture, ECF21, 20-24 June 2016, Catania, Italy, Procedia Structural Integrity 2 (2016), pp. 2833-2840.

Milliken (K.L.), "Late Diagenesis and Mass Transfer in Sandstone-Shale Sequences", Treatise on Geochemistry 7 (2003), pp. 159-190.

Millrath (S.), Kozlova (S.), Shimanovich (M.C.), "New Approach to Beneficiation of Dredged Material as a Filler", World Dredging (Mining \& Construction) 37 (11), 2001, pp. 8-20.

Mohammed (BS), Khed (VC), Nuruddin (MF), "A Review on Nano-Silica Based Concrete", Journal of Nanomed Nanoscience (5), 2017, pp. 1-4.

Musacchi (Jessica), Gonçalves (Teresa), "Influence of Nano-Lime and Nano-Silica Consolidants in the Drying Kinetics of Three Porous Building Materials", Proceedings of the Laboratório Nacional de Engenharia Civil, Lisboa, Brazil, 2014.

Otero (Jorge), Charola (Elena), Grissom (Carol), Starinieri (Vincenzo), “An Overview of Nanolime as a Consolidation Method for Calcareous Substrates”, Ge-conservación 11 (2017), pp. 71-78.

Overton (James), Some Aspects of Induced Development in Egypt Under Muhammad Ali Pasha and Khedive Ismail, Master Thesis, Simon Faster University, 1971.

Palomo (A.), Blanco-Varela (M.T.), Martinez-Ramirez (S.), Puertas (F.), Fortes, (C.), Historic Mortars: Characterization and Durability, New Tendencies for Research, Madrid, Spain, 2004.

Pandey (Parijat), Dahiya (Mandeep), "Carbon nanotubes: Types, Methods of Preparation and Applications", International Journal of Pharmaceutical Science and Research 1 (4), 2016, pp. 1521.

Pavía (Sara), Roundtree (Susan), "An Investigation into Irish Historical Ceramics: The Brick of Arch Hall, Wilkinstown, Co. Meath", Proceedings of the Royal Irish Academy 105 (6), 2005, pp. 221242.

Rashad (Alaa), "A Synopsis about the Effect of Nano-Titanium Dioxide on Some Properties of Cementitious Materials - A short guide for civil engineer", Rev. Adv. Mater. Sci. 40 (2015), pp. $72-$ 88 .

Robert (C.M.F.), Speweik (J.P.), "Repointing Mortar Joints in Historic Masonry Buildings", in Preservation Brief (2), National Park Service, HPS national park service, Washington DC, 1998.

Saleh (Najat), Ibrahim (Raheek), Salman (Ali), "Characterization of Nano-Silica Prepared from Local Silica Sand and its Application in Cement Mortar Using Optimization Technique", Advanced Powder Technology 26 (2015), pp.1123-1133.

Toumbakari (E.E.), Lime-Pozzolan-Cement Grouts and Their Structural Effects on Composite Masonry Walls, Ph.D., Thesis, Katholieke Universiteit Leuven, Faculteit Toegepaste Wetenschappen, Departement Burgerlijke Bouwkunde, Laboratorium Reyntjens, Heverlee, Belgium, 2002.

Vojtechovsky (Jan), Bayer (Karol), International workshop on Nano-Lime for Conservation of Stone, Plaster and Architectural Surfaces, Final Report, Pöide, Norway, 2016.

Xeidakis (G.), Koudoumakis (P.), Tsirambides (A.), "Road Construction on Swelling Soils: the Case of Strymi Soils, Rhodope, Thrace, Northern Greece", Bulletin of Engineering Geology and the Environment (63), Springer-Verlag, 2004, pp. 93-101.

Y1lmaz (I.), "Gypsum/anhydrite: Some Engineering Problems", Bulletin of Engineering geology and the Environment (59), Springer-Verlag, 2001, pp. 227-230.

Zainuddin (Atiqah), Mukri (Mazidah), Jamal (Norullain), Azmi (Azizah), Lat (Diana), "Study of Nano Koalinite as Additives in Kaolinite Clay to Develop New Clay Liner Design", Article Derived from the Project: Evaluation of Strength Characteristics for Palm Kernel Oil-Based Polyurethane (PKO-P) as a Ground Improvement Method, Malaysia, 2015, pp. 1-15.

\footnotetext{
- 251 - Nano Treatment of Decayed Cement-Lime Mortars from the Edfena Royal Palace
} 